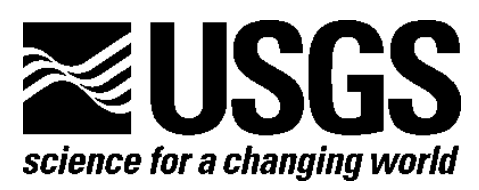

\title{
Cone Penetration Test and Soil Boring at the Bayside Groundwater Project Site in San Lorenzo, Alameda County, California
}

By Michael J. Bennett, Michelle Sneed, Thomas E. Noce, and John Tinsley III

Open-File Report 2009-1050

U.S. Department of the Interior

U.S. Geological Survey 


\title{
U.S. Department of the Interior \\ KEN SALAZAR, Secretary
}

\section{U.S. Geological Survey \\ Suzette M. Kimball, Acting Director}

\author{
U.S. Geological Survey, Reston, Virginia 2009
}

For product and ordering information:

World Wide Web: http://www.usgs.gov/pubprod

Telephone: 1-888-ASK-USGS

For more information on the USGS - the Federal source for science about the Earth, its natural and living resources, natural hazards, and the environment:

World Wide Web: http://www.usgs.gov

Telephone: 1-888-ASK-USGS

Suggested citation:

Bennett, M.J., Sneed, Michelle, Noce, T.E., and Tinsley, J.C. III, 2009, Cone penetration test and soil boring at the Bayside Groundwater Project in San Lorenzo, Alameda County, California: U.S. Geological Survey Open-File Report 2009-1050, 25 p. [http://pubs.usgs.gov/of/2009/1050].

Any use of trade, product, or firm names is for descriptive purposes only and does not imply endorsement by the U.S. Government.

Although this report is in the public domain, permission must be secured from the individual copyright owners to reproduce any copyrighted material contained within this report. 


\section{Contents}

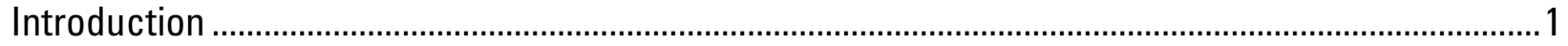

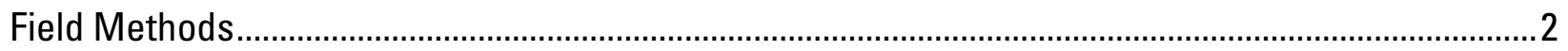

Seismic Cone Penetration Test (SCPT) ..............................................................................................

Continuous Hollow-Stem Auger Sampling ……………………………………………….....

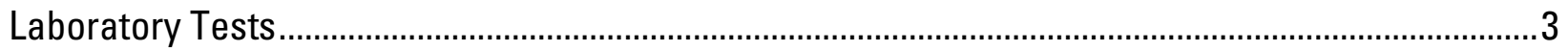

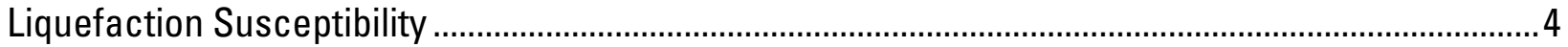

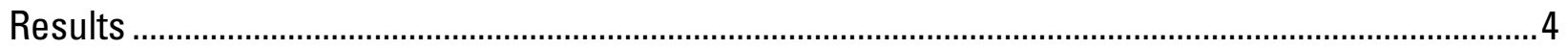

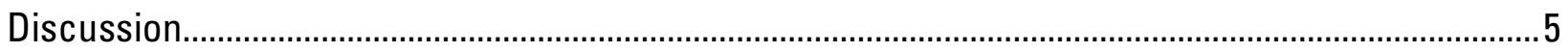

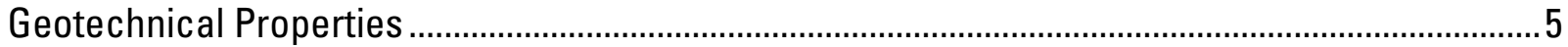

Stratigraphic Correlations ..........................................................................................................

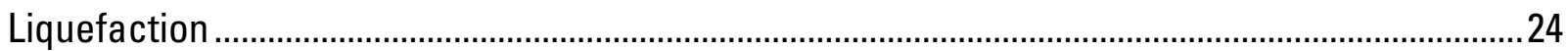

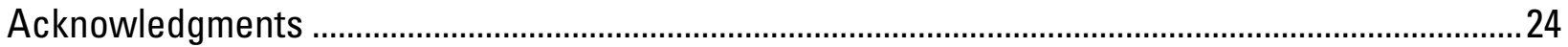

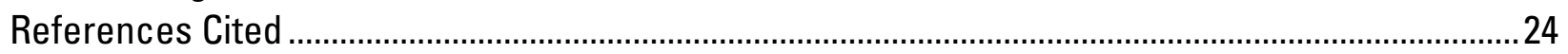

\section{Figures}

1. Location map showing the position of ALC085 on the shore of San Francisco Bay.......................2

2. Hogentogler log showing friction ratio, tip resistance, local friction, and

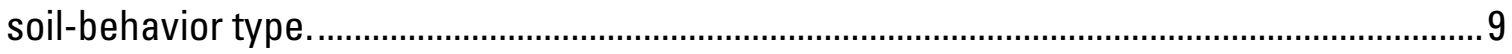

3. USGS geotechnical log showing sampled interval.................................................................. 10

4. Detailed USGS geotechnical log showing detailed sampling interval shown in figure $3 \ldots \ldots \ldots \ldots . . .11$

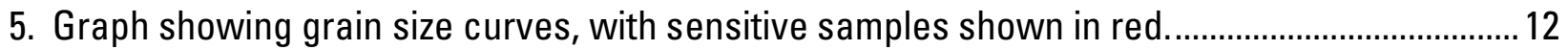

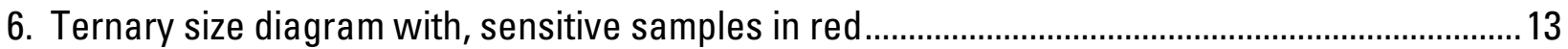

7. Graph showing side friction and tip resistance as a reference for variation of median size...... 14

8. Graph showing plasticity chart and the difference between alluvial and estuarine samples. .. 15

9. Graphs showing variation in Atterberg limits, water content, and sensitivity with depth............ 16

10. Graphs showing tip resistance as reference with variation in sensitivity, plasticity, and soil types.

11. Graphs showing water content vs. strength $(A)$ and density $(B)$; and median size vs. plasticity index $(C)$, and clay $(D)$............................................................................ 18

12. Graphs showing relations of liquidity index to sensitivity $(A)$, and to remolded strength $(B) \ldots 19$

13. Graphs showing relations between, $(A)$ clay content and liquid limit, and $(B)$ shear-wave

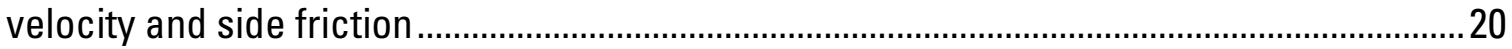

14. Graph showing the relations among tip resistance, and friction ratio, and

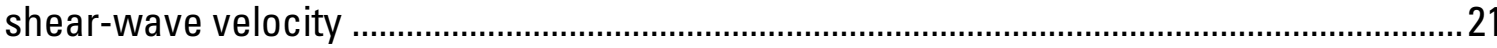

15. Graphs showing different means of classifying susceptiblity to liquefaction...............................22

\section{Tables}

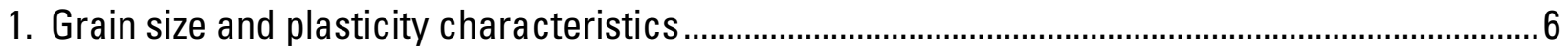

2. Strength properties and bulk density ..................................................................................

3. Summary of unit properties and characteristics ................................................................... 
Conversion Factors

SI to Inch/Pound

\begin{tabular}{|c|c|c|}
\hline Multiply & By & To obtain \\
\hline \multicolumn{3}{|c|}{ Length } \\
\hline centimeter $(\mathrm{cm})$ & 0.3937 & inch (in.) \\
\hline millimeter $(\mathrm{mm})$ & 0.03937 & inch (in.) \\
\hline meter $(\mathrm{m})$ & 3.281 & foot $(\mathrm{ft})$ \\
\hline kilometer (km) & 0.6214 & mile (mi) \\
\hline kilometer (km) & 0.5400 & mile, nautical (nmi) \\
\hline meter $(\mathrm{m})$ & 1.094 & yard (yd) \\
\hline \multicolumn{3}{|c|}{ Volume } \\
\hline cubic meter $\left(\mathrm{m}^{3}\right)$ & 6.290 & barrel (petroleum, 1 barrel $=42$ gal $)$ \\
\hline liter (L) & 33.82 & ounce, fluid (fl. oz) \\
\hline liter $(\mathrm{L})$ & 2.113 & $\operatorname{pint}(\mathrm{pt})$ \\
\hline liter $(\mathrm{L})$ & 1.057 & quart $(\mathrm{qt})$ \\
\hline liter (L) & 0.2642 & gallon (gal) \\
\hline cubic meter $\left(\mathrm{m}^{3}\right)$ & 264.2 & gallon (gal) \\
\hline cubic decimeter $\left(\mathrm{dm}^{3}\right)$ & 0.2642 & gallon (gal) \\
\hline cubic meter $\left(\mathrm{m}^{3}\right)$ & 0.0002642 & million gallons (Mgal) \\
\hline cubic centimeter $\left(\mathrm{cm}^{3}\right)$ & 0.06102 & cubic inch $\left(\mathrm{in}^{3}\right)$ \\
\hline cubic decimeter $\left(\mathrm{dm}^{3}\right)$ & 61.02 & cubic inch $\left(\mathrm{in}^{3}\right)$ \\
\hline liter (L) & 61.02 & cubic inch $\left(\mathrm{in}^{3}\right)$ \\
\hline cubic decimeter $\left(\mathrm{dm}^{3}\right)$ & 0.03531 & cubic foot $\left(\mathrm{ft}^{3}\right)$ \\
\hline cubic meter $\left(\mathrm{m}^{3}\right)$ & 35.31 & cubic foot $\left(\mathrm{ft}^{3}\right)$ \\
\hline cubic meter $\left(\mathrm{m}^{3}\right)$ & 1.308 & cubic yard $\left(\mathrm{yd}^{3}\right)$ \\
\hline cubic kilometer $\left(\mathrm{km}^{3}\right)$ & 0.2399 & cubic mile $\left(\mathrm{mi}^{3}\right)$ \\
\hline cubic meter $\left(\mathrm{m}^{3}\right)$ & 0.0008107 & acre-foot (acre-ft) \\
\hline cubic hectometer $\left(\mathrm{hm}^{3}\right)$ & 810.7 & acre-foot (acre-ft) \\
\hline
\end{tabular}


This page intentionally left blank 


\title{
Cone Penetration Test and Soil Boring at the Bayside Groundwater Project Site in San Lorenzo, Alameda County, California
}

\author{
By Michael J. Bennett ${ }^{1}$, Michelle Sneed ${ }^{2}$, Thomas E. Noce', and John C. Tinsley III'
}

\section{Introduction}

Aquifer-system deformation associated with ground-water-level changes is being investigated cooperatively by the U.S. Geological Survey (USGS) and the East Bay Municipal Utility District (EBMUD) at the Bayside Groundwater Project (BGP) near the modern San Francisco Bay shore in San Lorenzo, California (fig 1). As a part of this project, EBMUD has proposed an aquifer storage and recovery (ASR) program to store and recover as much as $3.78 \times 10^{4} \mathrm{~m}^{3} / \mathrm{d}$ of water. Water will be stored in a $30-\mathrm{m}$ sequence of coarse-grained sediment (the "Deep Aquifer") underlying the east bay alluvium and the adjacent ground-water basin. Storing and recovering water could cause subsidence and uplift at the ASR site and adjacent areas because the land surface will deform as aquifers and confining units elastically expand and contract with ASR cycles. The Deep Aquifer is overlain by more than $150 \mathrm{~m}$ of clayey finegrained sediments and underlain by comparable units. These sediments are similar to the clayey sediments found in the nearby Santa Clara Valley, where inelastic compaction resulted in about $4.3 \mathrm{~m}$ of subsidence near San Jose from 1910 to 1995 (Galloway and others, 1999) due to overdraft of the aquifer. The Deep Aquifer is an important regional resource, and EBMUD is required to demonstrate that ASR activities will not affect nearby ground-water management, salinity levels, or cause permanent land subsidence. Subsidence in the east bay area could induce coastal flooding and create difficulty conveying winter storm runoff from urbanized areas. The objective of the cooperative investigation is to monitor and analyze aquifer-system compaction and expansion, as well as consequent land subsidence and uplift resulting from natural causes and any anthropogenic causes related to ground-water development and ASR activities at the BGP. Therefore, soil properties related to compressibility (and the potential for deformation associated with ground-water-level changes) are of the most concern.

To achieve this objective, 3 boreholes were drilled at the BGP for the purpose of monitoring pore-fluid pressure changes and aquifer-system deformation. One 308-m deep borehole contains six piezometers, the other two boreholes are 182 and $299 \mathrm{~m}$ deep and contain a dual-stage extensometer. To investigate the physical properties of the sediments, two phases of subsurface exploration were conducted. In the first phase, a USGS drilling crew obtained numerous core samples, $5.8 \mathrm{~cm}$ in diameter by $1.5 \mathrm{~m}$ long. The samples were extracted between July 28, 2006, and August 5, 2006; nine samples were tested for this study at the USGS soils laboratory in Menlo Park, California.

Phase two began on June 22, 2006, when a seismic cone penetration test (SCPT) sounding was made to a depth of $32.3 \mathrm{~m}$. Additional field work was completed May 8, 2007, with a

${ }^{1}$ US Geological Survey, Menlo Park, California

${ }^{2}$ US Geological Survey, Sacramento, California 
hollow-stem auger boring that took continuous 9.8-cm-diameter samples from the depth interval of 6.1 to $10.7 \mathrm{~m}$ to supplement poor recovery from the first phase of sampling. These samples were also tested in the soils laboratory at the USGS.

\section{Field Methods}

\section{Seismic Cone Penetration Test (SCPT)}

A SCPT was made at ALC085 in the BGP (fig. 1) to determine stratification, soil type, shearwave velocity, density, consistency, and penetration resistance. We used a Hogentogler 10-ton digital subtraction cone with a single-element strain gauge that eliminates mechanical coupling effects. The cone has internal electronic power amplification and regulation mounted directly behind the transducer, eliminating the effect of cable resistance on the measurements. In addition, the cone is temperature compensated to reduce errors due to temperature shift.

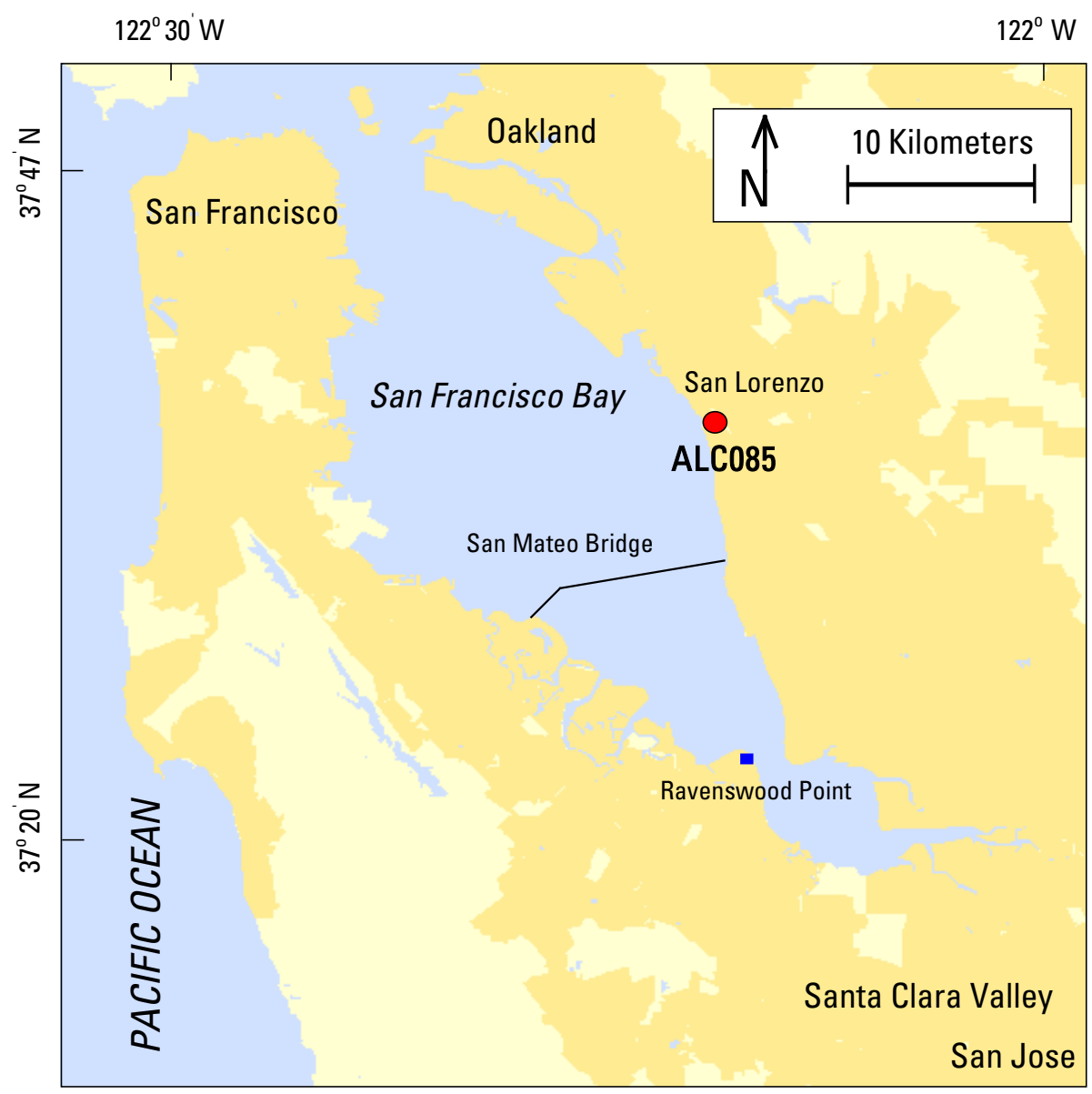

Figure 1. Location map showing position of ALC085 at the Bayside Groundwater Project on the shore of San Francisco Bay. 
A strain gauge is located in a 3.6-cm diameter housing, the tip of which is a $60^{\circ} 10-\mathrm{cm}^{2}$ cone. Cone resistance is measured at the tip $\left(q_{c}\right)$; side friction resistance $\left(f_{s}\right)$ is measured along a 150$\mathrm{cm}^{2}$ sleeve located behind the cone. The cone is advanced into the soil at a rate of $2 \mathrm{~cm} / \mathrm{s}$. Recording channels include (1) tip resistance, (2) side friction resistance, (3) two channels of inclination, and (4) two channels to measure-shear wave propagation velocity. Tip resistance and the ratio between side friction resistance and tip resistance (friction ratio, $R_{f}$, in percent) are used to infer soil type. The penetration resistance, which is digitized at depth intervals of $5 \mathrm{~cm}$, permits detailed inferences about stratigraphy and lithology. The procedures and equipment meet the requirements of ASTM D3441-79 (American Society for Testing and Materials, 1983).

Downhole shear-wave velocity can also be measured with the seismic cone during soundings. The shear-wave velocity can be used in conjunction with an estimate or measurement of the soil density to determine the dynamic shear modulus of the soil at low strain values. Performing this measurement during SCPT soundings is faster and less expensive than standard crosshole or downhole seismic tests. All of the electronics are in the cone, eliminating the need for drilling and casing boreholes. The cone itself is in direct contact with the soil and causes less disturbance of the insitu conditions than casing a hole. The near-vertical propagation of the shear waves downward allows the shear waves to pass down through the soil, rather than across the horizontal layer, thus reducing the effect of refraction on the results. A shear wave is generated at the surface by horizontally striking a steel plate with a sledge hammer. The resulting wave form is recorded and transmitted to a computer. The arrival time of the shear wave can then be determined. The change in depth between the current test and the previous test is divided by the difference in the arrival times to determine the average shear-wave velocity for that depth interval.

\section{Continuous Hollow-Stem Auger Sampling}

A hollow-stem auger boring was made $1.5 \mathrm{~m}$ away from the SCPT sounding to obtain samples for soil-index tests (sampling was conducted about 1 year after the SCPT). Continuous samples were taken in thin-walled 7.6-cm-diameter by $91-\mathrm{cm}-$ long Shelby tubes used with hollow-stem augers of outside and inside diameters of $25.4 \mathrm{~cm}$ and $10.2 \mathrm{~cm}$, respectively. Tubes were slowly pushed into the soil past the end of the auger. The auger was then advanced the sampling length; the tube was then rotated to shear off the sample from the undisturbed soil. Tubes were capped and sealed with tape; no wax was used for sealing.

\section{Laboratory Tests}

Index tests conducted in the laboratory include: (1) grain size (D422-63, ASTM, 1983), (2) water content (D2216, ASTM, 1983), and (3) Atterberg limits - liquid limit (D423-66, ASTM, 1983) and plastic limit (D424-59, ASTM, 1983). Two important derived properties related to the Atterberg limits are plasticity index and liquidity index. The plasticity index is the difference between the liquid limit and the plastic limit. The liquidity index is used to scale the natural water content to the Atterberg limits; it is the ratio of the difference between the natural water content and the plastic limit to the plasticity index. Samples were classified using the Unified Soil Classification (USC) (D2488-69, ASTM, 1983) as modified by Howard (1984). Shelby-tube samples were cut into $15-\mathrm{cm}$ lengths for bulk density and vane tests. The length of each subsample was measured and the tube and sample weighed. Next, shear strength was measured using a Wykeham Farrance laboratory-vane-shear device with the sample still in the 
tube. The vane $(12.7 \times 12.7 \mathrm{~mm})$ was pushed into the sample $4 \mathrm{~cm}$ and rotated at 90 degrees per minute. Peak strength, residual strength, and remolded strength were measured. Sensitivity was then determined from the ratio of peak strength to remolded strength. After the strength measurements, the vane was removed and a water-content sample was taken from the area of the vane test. The sample was then extruded and described. A pocket penetrometer was used to measure compressive strength after the sample was extruded. Results of the laboratory tests are listed in table 1 (grain-size and plasticity characteristics) and table 2 (strength characteristics).

\section{Liquefaction Susceptibility}

Liquefaction susceptibility was determined in several ways. Tip resistance and side friction resistance from the cone penetrometer were used to calculate liquefaction potential index (LPI). LPI incorporates liquefaction factors of safety and thickness of liquefiable layers according to depth (Iwasaki and others, 1978). LPI assumes that the severity of liquefaction is proportional to (1) how thick the liquefied layers are, (2) how close to the ground surface the liquefied layers are, and (3) how much less than 1 the factor of safety is, where factor of safety is the ratio of the soil capacity to resist liquefaction to seismic demand imposed by the earthquake. Toprak and Holzer (2003) independently correlated LPI with liquefaction effects in historical California earthquakes. They found that sand boils typically occur when LPI is equal to or greater than 5 and that lateral spreads occur when LPI is equal to or greater than 12 .

Seed and Idriss (1982) suggest guidelines for determining the limits of liquefaction for clayey soils. They suggest that clayey soils are susceptible to liquefaction if (1) they have less than 15 percent clay, (2) the liquid limit is less than 35, and (3) the water content is greater than 90 percent of the liquid limit. Bray and Sancio (2006) have suggested that a plasticity index less than 12 is also a requirement.

\section{Results}

Results of the grain-size and Atterberg tests are listed in table 1. Samples labeled ALC085-1 were obtained in the first phase of sampling; none of these samples had water content measured because they had been allowed to dry out. Samples labeled ALC085-2 were part of the second phase of sampling and were tested for grain size and Atterberg limits (including water content). Results of strength and density measurements are listed in table 2; only samples from the second phase of sampling are included in this table. A summary of the properties is shown in table 3.

The results from the cone penetration test are shown in figure 2. The figure is a product of the Hogentogler Cone Plot program and consists of four columns: (1) friction ratio (side friction resistance/tip resistance, percent) is an indication of soil type - low numbers indicate sandy soils and numbers above 2 indicate clayey soils; (2) tip resistance is an indication of bearing capacity; (3) local friction is equivalent to side friction resistance; (4) soil behavior type is a 12-zone classification based on soil behavior by described Robertson (1990).

The USGS geotechnical log showing median grain size, fines content, Unified Soil Classification, unit shear-wave velocity, graphic log, and a brief description, is shown in figure 3. Results have been edited in this figure because of the close spacing of the samples. A detailed view of the interval between depths of 6 and $11 \mathrm{~m}$ is shown in figure. 4 . 


\section{Discussion}

\section{Geotechnical Properties}

Two stratigraphic intervals stand out in this boring. The first is the Holocene bay mud (1-3.5 $\mathrm{m})$. This unit contains the finest grained sediment, the highest water content, the lowest shear wave velocity, the lowest side friction (correlated with strength), and the highest liquidity index. On the basis of its high water content and low strength, the bay mud has long been recognized by geologists and engineers to be the most problematic geologic unit in terms of settlement and foundation stability.

The second interval that stands out occurs between 8.0 and $8.8 \mathrm{~m}$ and is referred to as the sensitive zone. This interval shares some similarities with the Holocene bay mud. The water content and the liquidity index are higher than surrounding sediment, and tip and side friction resistance and vane shear tests show that it has lower strength than the surrounding sediment. This interval also shows some differences from bay mud. The grain size is coarser in the sensitive zone compared to the bay mud. The fat clay $(\mathrm{CH})$ bay mud has an average median size of $0.005 \mathrm{~mm}$ with an average of 3 percent sand, whereas the sensitive zone (lean clay with sand, CL) has an average median size of $0.030 \mathrm{~mm}$ and an average sand content of 24 percent. The bay mud has an upward-fining grain size, whereas the sensitive zone forms the only well developed coarsening-upward sequence in the borehole. The key properties within the sensitive zone are liquidity index and sensitivity. Liquidity index is directly related to sensitivity (fig.12A) and inversely related to remolded shear strength (fig. 12B). Torrance (1983) reviews the characteristics of sensitive clays and describes three classification systems (p. 548). With an average sensitivity of 8.6 , the 8.0 to 8.8 -m interval could be classed as (1) extra sensitive, (2) slightly quick, or (3) medium high sensitivity.

Grain-size distributions are shown two different ways: the first (fig. 5) shows the distribution of grain-size curves, the cumulative percent finer plotted against the grain size in $\mathrm{mm}$; the second (fig. 6) shows the distribution of grain sizes in a ternary diagram. Both graphs have five samples highlighted that are classified as "sensitive" in regards to strength. The relations between the tip resistance and side friction resistance, median grain size, size fractions, and shear-wave velocity are shown in figure 7.

The plasticity of the samples is shown on the classification chart (fig. 8). Figure $9 A$ shows the variation in liquid limit, plastic limit, and natural water content with depth for the entire sampled interval. Figure $9 B$ shows the same properties with sensitivity in the depth interval $0-11 \mathrm{~m}$, to emphasize the detailed results of phase two. Sensitivity is also shown in figure $10 A$ with soil type and plasticity (fig. 10B) and with peak and remolded shear strength and liquidity index (fig. 10C). The relations between natural water content and peak shear strength and density are shown in figures $11 A$ and $B$, respectively. The relations between plasticity and median grain size and clay content are shown in figures $11 C$ and $D$, respectively.

The relations between liquidity index and sensitivity, and remolded strength and are shown in figures $12 A$ and $B$, respectively. The relation between clay content and liquid limit is shown in figure $13 \mathrm{~A}$; the relation between shear-wave velocity and side friction is shown in figure $13 B$. The relation between tip resistance and friction ratio and shear-wave velocity is shown in figure 14 .

There are several ways to determine if a soil sample is susceptible to liquefaction using soil index properties. Figure 15 shows three methods to determine liquefaction susceptibility: (1) liquid limit and 5 micron clay fraction (fig.15A), (2) liquid limit and water content (fig. 15B), and (3) plasticity index and water content to liquid limit ratio (fig. 15C). In addition, LPI was calculated using a water table of $1 \mathrm{~m}$, a $\boldsymbol{M} 7$ earthquake, and an acceleration of $0.3 \mathrm{~g}$.. 
Table 1. Grain size and plasticity characteristics for samples from ALC085.

\begin{tabular}{|c|c|c|c|c|c|c|c|c|c|c|c|c|c|c|c|c|c|}
\hline Index \# & Site & $\begin{array}{c}\text { Sample } \\
\text { number* }\end{array}$ & $\begin{array}{c}\text { Depth interval, } \\
\mathrm{ft}\end{array}$ & Depth, $\mathrm{m}$ & Depth, ft & $\underset{>4.75 \mathrm{~mm}}{\text { Gravel }}$ & $\begin{array}{c}\text { Sand } \\
4.75-0.075 \mathrm{~mm}\end{array}$ & $\underset{\substack{0.075-0.005 \\
\mathrm{~mm}}}{\text { Silt }}$ & $\begin{array}{c}\text { Clay } \\
<0.005 \\
\mathrm{~mm}\end{array}$ & $\mathrm{D}_{50} \quad \mathrm{~mm}$ & $\mathrm{Wn}$ & $\begin{array}{c}\text { Liquid } \\
\text { limit }\end{array}$ & $\begin{array}{c}\text { Plastic } \\
\text { limit }\end{array}$ & PI & $\begin{array}{c}\text { Liquidity } \\
\text { index }\end{array}$ & USC & Description \\
\hline 1 & ALC085-1 & (1) 2-c-1 & $5-10$ & 1.92 & 6.3 & 0 & 3 & 30 & 67 & 0.002 & & 87 & 36 & 51 & & $\overline{\mathrm{CH}}$ & Fat clay \\
\hline 2 & ALC085-2 & (2) 1 & 7' grab & 2.13 & 7.0 & 0 & 1 & 38 & 61 & 0.003 & 72.8 & 82 & 36 & 46 & 0.80 & $\mathrm{CH}$ & Fat clay \\
\hline 3 & ALC085-1 & \begin{tabular}{|l} 
(1) 3-c-1a \\
\end{tabular} & $10-15$ & 3.25 & 10.7 & 0 & 6 & 56 & 38 & 0.010 & & 52 & 23 & 29 & & $\mathrm{CH}$ & Fat clay \\
\hline 4 & ALC085-1 & (1) 3-c-1b & $10-15$ & 4.06 & 13.3 & 0 & 32 & 42 & 26 & 0.035 & & 31 & 15 & 16 & & CLS & Sandy lean clay \\
\hline 5 & ALC085-1 & (1) 4-c-1 & $15-20$ & 4.91 & 16.1 & 0 & 31 & 42 & 27 & 0.036 & & 36 & 16 & 20 & & CLS & Sandy lean clay \\
\hline 6 & ALC085-2 & (2) $2-\mathrm{a}$ & $20-22.5^{\prime}$ & 6.17 & 20.3 & 0 & 11 & 54 & 35 & 0.008 & & 45 & 23 & 22 & & $\mathrm{CL}$ & Lean clay \\
\hline 7 & ALC085-2 & (2) 2-b & $20-22.5^{\prime}$ & 6.32 & 20.8 & 0 & 16 & 47 & 37 & 0.015 & 29.1 & 48 & 22 & 26 & 0.27 & $\mathrm{CL}$ & Lean clay with sand \\
\hline 8 & ALC085-2 & (2) $2-\mathrm{c}-1$ & $20-22.5^{\prime}$ & 6.48 & 21.3 & 0 & 20 & 58 & 22 & 0.021 & 23.7 & 32 & 17 & 15 & 0.45 & $\mathrm{CL}$ & Lean clay with sand \\
\hline 9 & ALC085-2 & (2) 2-d & $20-22.5^{\prime}$ & 6.63 & 21.8 & 0 & 14 & 60 & 26 & 0.020 & 19.3 & 35 & 19 & 16 & 0.02 & $\mathrm{CL}$ & Lean clay \\
\hline 10 & ALC085-2 & (2) $2-\mathrm{e}$ & $20-22.5^{\prime}$ & 6.78 & 22.3 & 0 & 16 & 56 & 28 & 0.016 & 18.8 & 32 & 19 & 13 & -0.02 & $\mathrm{CL}$ & Lean clay with sand \\
\hline 11 & ALC085-2 & (2) $3 \mathrm{a}$ & $22.5-25^{\prime}$ & 7.12 & 23.4 & 0 & 19 & 50 & 31 & 0.019 & 19.4 & 38 & 18 & 20 & 0.07 & $\mathrm{CL}$ & Lean clay with sand \\
\hline 12 & ALC085-2 & (2) $3 \mathrm{~b}$ & $22.5-25^{\prime}$ & 7.24 & 23.8 & 0 & 21 & 51 & 28 & 0.018 & 19.8 & 35 & 17 & 18 & 0.16 & $\mathrm{CL}$ & Lean clay with sand \\
\hline 13 & ALC085-2 & (2) $3 \mathrm{c}$ & $22.5-25^{\prime}$ & 7.39 & 24.3 & 0 & 22 & 47 & 31 & 0.022 & 19.5 & 42 & 19 & 23 & 0.02 & $\mathrm{CL}$ & Lean clay with sand \\
\hline 14 & ALC085-2 & (2) 3d & $22.5-25^{\prime}$ & 7.54 & 24.8 & 0 & 25 & 44 & 31 & 0.023 & 22.7 & 36 & 19 & 17 & 0.22 & $\mathrm{CL}$ & Lean clay with sand \\
\hline 15 & ALC085-2 & (2) $4 \mathrm{a}$ & $25-27.5^{\prime}$ & 7.70 & 25.3 & 0 & 22 & 51 & 27 & 0.019 & 22.6 & 42 & 21 & 21 & 0.08 & $\mathrm{CL}$ & Lean clay with sand \\
\hline 16 & ALC085-2 & (2) $4 \mathrm{~b}$ & $25-27.5^{\prime}$ & 7.85 & 25.8 & 0 & 17 & 45 & 38 & 0.008 & 27.1 & 44 & 22 & 22 & 0.23 & $\mathrm{CL}$ & Lean clay with sand \\
\hline 17 & ALC085-2 & (2) $4 \mathrm{c}$ & $25-27.5^{\prime}$ & 8.00 & 26.3 & 0 & 35 & 47 & 18 & 0.039 & 24.4 & 30 & 19 & 11 & 0.49 & CLS & Sandy lean clay \\
\hline 18 & ALC085-2 & (2) $4 d$ & $25-27.5^{\prime}$ & 8.15 & 26.8 & 0 & 25 & 60 & 15 & 0.036 & 23.8 & 30 & 18 & 12 & 0.48 & $\mathrm{CL}$ & Lean clay with sand \\
\hline 19 & ALC085-2 & (2) $4 \mathrm{e}$ & $25-27.5^{\prime}$ & 8.31 & 27.3 & 0 & 24 & 54 & 22 & 0.030 & 25.7 & 29 & 18 & 11 & 0.70 & $\mathrm{CL}$ & Lean clay with sand \\
\hline 20 & ALC085-2 & (2) $5 \mathrm{a}$ & $27.5-30$ & 8.61 & 28.3 & 0 & 17 & 62 & 21 & 0.023 & 20.3 & 30 & 17 & 13 & 0.25 & $\mathrm{CL}$ & Lean clay with sand \\
\hline 21 & ALC085-2 & (2) $5 \mathrm{~b}$ & $27.5-30$ & 8.76 & 28.8 & 0 & 18 & 58 & 24 & 0.022 & 21 & 28 & 16 & 12 & 0.42 & $\mathrm{CL}$ & Lean clay with sand \\
\hline 22 & ALC085-2 & (2) $5 \mathrm{c}$ & $27.5-30$ & 8.92 & 29.3 & 0 & 23 & 53 & 24 & 0.026 & 18.4 & 29 & 17 & 12 & 0.12 & $\mathrm{CL}$ & Lean clay with sand \\
\hline 23 & ALC085-2 & (2) $5 \mathrm{~d}$ & $27.5-30$ & 9.07 & 29.8 & 0 & 30 & 50 & 20 & 0.030 & 18.5 & 30 & 16 & 14 & 0.18 & CLS & Sandy lean clay \\
\hline 24 & ALC085-2 & (2) $6 \mathrm{a}$ & $30-32.5^{\prime}$ & 9.39 & 30.8 & 0 & 36 & 44 & 20 & 0.035 & 18.2 & 31 & 17 & 14 & 0.09 & CLS & Sandy lean clay \\
\hline 25 & ALC085-2 & (2) $6 \mathrm{~b}$ & $30-32.5^{\prime}$ & 9.53 & 31.3 & 0 & 37 & 43 & 20 & 0.038 & 18.2 & 33 & 17 & 16 & 0.08 & CLS & Sandy lean clay \\
\hline 26 & ALC085-2 & (2) $6 \mathrm{c}$ & $30-32.5^{\prime}$ & 9.68 & 31.8 & 0 & 40 & 40 & 20 & 0.046 & 17.8 & 32 & 17 & 15 & 0.05 & CLS & Sandy lean clay \\
\hline 27 & ALC085-2 & (2) $6 \mathrm{~d}$ & $30-32.5^{\prime}$ & 9.83 & 32.3 & 0 & 38 & 40 & 22 & 0.046 & 18.2 & 32 & 17 & 15 & 0.08 & CLS & Sandy lean clay \\
\hline 28 & ALC085-2 & (2) $7 a$ & $32.5-35$ & 10.02 & 32.9 & 0 & 39 & 41 & 20 & 0.050 & 18.9 & 28 & 19 & 9 & -0.01 & CLS & Sandy lean clay \\
\hline 29 & ALC085-2 & (2) $7 \mathrm{~b}$ & $32.5-35$ & 10.13 & 33.3 & 0 & 38 & 44 & 18 & 0.051 & 19.2 & 30 & 19 & 11 & 0.02 & CLS & Sandy lean clay \\
\hline 30 & ALC085-2 & (2) $7 \mathrm{c}$ & $32.5-35$ & 10.29 & 33.8 & 0 & 37 & 46 & 17 & 0.051 & 20.8 & 25 & 18 & 7 & 0.40 & CLS & Sandy lean clay \\
\hline 31 & ALC085-2 & (2) 7d & $32.5-35$ & 10.44 & 34.3 & 0 & 36 & 46 & 18 & 0.055 & 20.5 & 30 & 19 & 11 & 0.14 & CLS & Sandy lean clay \\
\hline 32 & ALC085-2 & (2) $7 \mathrm{e}$ & $32.5-35$ & 10.59 & 34.8 & 0 & 38 & 45 & 17 & 0.057 & 20.7 & 26 & 20 & 6 & 0.12 & CL-ML & Sandy silty clay \\
\hline 33 & ALC085-1 & (1) 12 -c-1 & $55-60$ & 17.47 & 57.3 & 0 & 6 & 60 & 34 & 0.015 & & 41 & 18 & 23 & & $\mathrm{CL}$ & Lean clay \\
\hline 34 & ALC085-1 & \begin{tabular}{|l|} 
(1) 15 -c- 1 \\
(a)
\end{tabular} & $70-75$ & 21.83 & 71.6 & 0 & 32 & 51 & 17 & 0.043 & & 31 & 17 & 14 & & CLS & Sandy lean clay \\
\hline 35 & ALC085-1 & \begin{tabular}{|l|} 
(1) $18-\mathrm{c}-1 \mathrm{a}$ \\
\end{tabular} & $85-90$ & 26.24 & 86.1 & 0 & 8 & 78 & 14 & 0.025 & & 36 & 24 & 12 & & $\mathrm{CL}$ & Lean clay \\
\hline 36 & ALC085-1 & (1) $18-\mathrm{c}-1 \mathrm{~b}$ & $85-90$ & 26.67 & 87.5 & 0 & 1 & 58 & 41 & 0.007 & & 61 & 24 & 37 & & $\mathrm{CH}$ & Fat clay \\
\hline 37 & ALC085-1 & \begin{tabular}{|l|} 
(1) $19-\mathrm{c}-1$ \\
\end{tabular} & $90-95$ & 28.52 & 93.6 & 0 & 3 & 54 & 43 & 0.007 & & 54 & 19 & 35 & & $\mathrm{CH}$ & Fat clay \\
\hline 38 & ALC085-1 & \begin{tabular}{|l|} 
(1) $22-\mathrm{c}-1$ \\
\end{tabular} & $105-110$ & 33.28 & 109.2 & 0 & 1 & 67 & 32 & 0.011 & & 52 & 21 & 31 & & $\mathrm{CH}$ & Fat clay \\
\hline 39 & ALC085-1 & (1) 25 -c- 1 & $120-125$ & 37.82 & 124.1 & 0 & 48 & 41 & 11 & 0.067 & & 27 & 19 & 8 & & CLS & Sandy lean clay \\
\hline
\end{tabular}

* Phase one sample (1) and phase two sample (2) 
Table 2. Strength characteristics for samples from ALC085

\begin{tabular}{|c|c|c|c|c|c|c|c|c|c|c|c|c|}
\hline $\begin{array}{c}\text { Index } \\
\quad \#\end{array}$ & Site & $\begin{array}{l}\text { Sample } \\
\text { number }\end{array}$ & $\begin{array}{c}\text { Depth } \\
\text { interval, } \mathrm{ft}\end{array}$ & Depth, m & Depth, ft & $\begin{array}{c}\text { Unified Soil } \\
\text { Classification }\end{array}$ & Description & $\begin{array}{c}\text { Peak } \\
\text { strength, } \\
\mathrm{kN} / \mathrm{m}^{2}\end{array}$ & $\begin{array}{c}\text { Residual } \\
\text { strength, } \\
\mathrm{kN} / \mathrm{m}^{2}\end{array}$ & $\begin{array}{l}\text { Remolded } \\
\text { strength, } \\
\mathrm{kN} / \mathrm{m}^{2}\end{array}$ & $\begin{array}{c}\text { Sensitivity } \\
\text { peak/remolded }\end{array}$ & $\begin{array}{l}\text { Density, } \\
\mathrm{g} / \mathrm{cm}^{3}\end{array}$ \\
\hline 6 & ALC085-2 & 2-a & $20-22.5^{\prime}$ & 6.17 & 20.3 & $\mathrm{CL}$ & Lean clay & & & & & 1.81 \\
\hline 7 & ALC085-2 & 2-b & $20-22.5^{\prime}$ & 6.32 & 20.8 & $\mathrm{CL}$ & Lean clay with sand & 85.2 & 59.8 & 28.8 & 3.0 & 1.94 \\
\hline 8 & ALC085-2 & 2-c-1 & $20-22.5^{\prime}$ & 6.48 & 21.3 & $\mathrm{CL}$ & Lean clay with sand & 116.2 & 60.9 & 34.3 & 3.4 & 2.06 \\
\hline 9 & ALC085-2 & 2-d & $20-22.5^{\prime}$ & 6.63 & 21.8 & $\mathrm{CL}$ & Lean clay & 160.5 & 84.1 & 45.4 & 3.5 & 2.1 \\
\hline 11 & ALC085-2 & $3 \mathrm{a}$ & $22.5-25^{\prime}$ & 7.12 & 23.4 & $\mathrm{CL}$ & Lean clay with sand & 158.3 & 81.9 & 65.3 & 2.4 & \\
\hline 12 & ALC085-2 & $3 b$ & $22.5-25^{\prime}$ & 7.24 & 23.8 & $\mathrm{CL}$ & Lean clay with sand & 170.4 & 77.5 & 57.6 & 3.0 & 2.1 \\
\hline 13 & ALC085-2 & $3 \mathrm{c}$ & $22.5-25^{\prime}$ & 7.39 & 24.3 & $\mathrm{CL}$ & Lean clay with sand & 222.5 & 111.8 & 81.9 & 2.7 & 2.06 \\
\hline 14 & ALC085-2 & $3 \mathrm{~d}$ & $22.5-25^{\prime}$ & 7.54 & 24.8 & $\mathrm{CL}$ & Lean clay with sand & 148.3 & 71.9 & 48.7 & 3.0 & 2.01 \\
\hline 16 & ALC085-2 & $4 b$ & $25-27.5^{\prime}$ & 7.85 & 25.8 & $\mathrm{CL}$ & Lean clay with sand & 107.4 & 69.7 & 26.6 & 4.0 & 1.96 \\
\hline 17 & ALC085-2 & $4 \mathrm{c}$ & $25-27.5^{\prime}$ & 8.00 & 26.3 & CLS & Sandy lean clay & 75.3 & 46.5 & 12.2 & 6.2 & 2.01 \\
\hline 19 & ALC085-2 & $4 e$ & $25-27.5^{\prime}$ & 8.31 & 27.3 & CL & Lean clay with sand & 67.5 & 31 & 5.5 & 12.3 & 1.91 \\
\hline 20 & ALC085-2 & $5 \mathrm{a}$ & $27.5-30$ & 8.61 & 28.3 & $\mathrm{CL}$ & Lean clay with sand & 102.9 & 38.7 & 13.3 & 7.7 & 2.05 \\
\hline 21 & ALC085-2 & $5 b$ & $27.5-30$ & 8.76 & 28.8 & CL & Lean clay with sand & 148.3 & 54.2 & 19.9 & 7.5 & 2.11 \\
\hline 22 & ALC085-2 & $5 \mathrm{c}$ & $27.5-30$ & 8.92 & 29.3 & CL & Lean clay with sand & 203.6 & 60.9 & 50.9 & 4.0 & 2.12 \\
\hline 23 & ALC085-2 & $5 \mathrm{~d}$ & $27.5-30$ & 9.07 & 29.8 & CLS & Sandy lean clay & 182.6 & 62 & 39.8 & 4.6 & 2.13 \\
\hline 24 & ALC085-2 & $6 a$ & $30-32.5^{\prime}$ & 9.39 & 30.8 & CLS & Sandy lean clay & 150.5 & 79.7 & 38.7 & 3.9 & \\
\hline 25 & ALC085-2 & $6 b$ & $30-32.5^{\prime}$ & 9.53 & 31.3 & CLS & Sandy lean clay & 240.2 & 126.2 & 76.4 & 3.1 & 2.14 \\
\hline 26 & ALC085-2 & $6 \mathrm{c}$ & $30-32.5^{\prime}$ & 9.68 & 31.8 & CLS & Sandy lean clay & 239.1 & 115.1 & 71.9 & 3.3 & 2.14 \\
\hline 27 & ALC085-2 & 6d & $30-32.5^{\prime}$ & 9.83 & 32.3 & CLS & Sandy lean clay & 135 & 63.1 & 38.7 & 3.5 & 2.13 \\
\hline 29 & ALC085-2 & $7 b$ & $32.5-35$ & 10.13 & 33.3 & CLS & Sandy lean clay & 80.8 & 59.8 & 23.2 & 3.5 & 2.1 \\
\hline 30 & ALC085-2 & $7 \mathrm{c}$ & $32.5-35$ & 10.29 & 33.8 & CLS & Sandy lean clay & 106.2 & 69.7 & 24.3 & 4.4 & 2 \\
\hline 31 & ALC085-2 & $7 \mathrm{~d}$ & $32.5-35$ & 10.44 & 34.3 & CLS & Sandy lean clay & 75.3 & 50.9 & 15.5 & 4.9 & 2.07 \\
\hline 32 & ALC085-2 & $7 \mathrm{e}$ & $32.5-35$ & 10.59 & 34.8 & CL-ML & Sandy silty clay & 96.3 & 38.7 & 21 & 4.6 & 2.08 \\
\hline
\end{tabular}


Table 3. Summary of unit properties and characteristics of samples from ALC085

\begin{tabular}{|c|c|c|c|c|c|c|c|c|c|c|c|c|c|c|c|}
\hline $\begin{array}{c}\text { Depth } \\
\text { range, } \\
\mathrm{m}\end{array}$ & $\begin{array}{c}\text { Avg } \\
\text { gravel } \\
\% \\
\end{array}$ & $\begin{array}{c}\text { Avg } \\
\text { sand } \\
\% \\
\end{array}$ & $\begin{array}{c}\text { Avg } \\
\text { silt } \\
\% \\
\end{array}$ & $\begin{array}{l}\text { Avg } \\
\text { clay } \\
\% \\
\end{array}$ & $\begin{array}{l}\text { Avg } \\
\mathrm{D}_{50} \\
\mathrm{~mm} \\
\end{array}$ & $\begin{array}{l}\text { Avg } \\
\mathrm{W}_{\mathrm{n}} \\
\% \\
\end{array}$ & $\begin{array}{c}\text { Avg } \\
\text { liquid } \\
\text { limit } \\
\end{array}$ & $\begin{array}{l}\text { Avg } \\
\text { plastic } \\
\text { limit } \\
\end{array}$ & $\begin{array}{c}\text { Avg } \\
\text { plasticity } \\
\text { index }\end{array}$ & $\begin{array}{c}\text { Avg } \\
\text { liquidity } \\
\text { index } \\
\end{array}$ & $\begin{array}{c}\text { Unified Soil } \\
\text { Classification }\end{array}$ & $\begin{array}{c}\text { Avg } \\
\text { peak } \\
\text { strength } \\
\mathrm{kN} / \mathrm{m}^{2} \\
\end{array}$ & $\begin{array}{l}\text { Avg } \\
\text { remolded } \\
\text { strength } \\
\mathrm{kN} / \mathrm{m}^{2} \\
\end{array}$ & $\begin{array}{c}\text { Avg } \\
\text { sensitivity } \\
\text { peak/remolded }\end{array}$ & $\begin{array}{c}\text { Avg } \\
\text { density } \\
\mathrm{g} / \mathrm{cm}^{3} \\
\end{array}$ \\
\hline $1.0-3.5$ & 0 & 3 & 41 & 55 & 0.005 & 73 & 74 & 32 & 42 & 0.80 & $\mathrm{CH}$ & & & & \\
\hline $3.5-5.4$ & 0 & 32 & 42 & 27 & 0.036 & & 34 & 16 & 18 & & CLS & & & & \\
\hline 5.4-8.0 & 0 & 18 & 51 & 30 & 0.017 & 22 & 39 & 20 & 19 & 0.15 & $\mathrm{CL}$ & 154 & 51 & 3.1 & 2.01 \\
\hline $8-8.8$ & 0 & 24 & 56 & 20 & 0.030 & 23 & 29 & 18 & 12 & 0.47 & $\mathrm{CL}$ & 91 & 12 & 8.6 & 2.01 \\
\hline $8.8-9.7$ & 0 & 34 & 45 & 21 & 0.037 & 18 & 31 & 17 & 14 & 0.10 & CLS & 203 & 56 & 3.8 & 2.13 \\
\hline $9.7-10.7$ & 0 & 38 & 44 & 18 & 0.053 & 20 & 28 & 19 & 9 & 0.13 & CLS & 99 & 25 & 4.2 & 2.08 \\
\hline
\end{tabular}

\begin{tabular}{|l|c|c|c|c|c|c|}
\hline $\begin{array}{c}\text { Depth } \\
\text { range, } \\
\mathrm{m}\end{array}$ & Unit & $\begin{array}{c}\text { Avg } \\
\text { tip } \\
\mathrm{MN} / \mathrm{m}^{2}\end{array}$ & $\begin{array}{c}\text { Avg } \\
\text { friction } \\
\mathrm{kN} / \mathrm{m}^{2}\end{array}$ & $\begin{array}{c}\text { Avg } \\
\text { ratio } \\
\text { percent }\end{array}$ & $\begin{array}{c}\text { Avg } \\
\text { zone }\end{array}$ & $\begin{array}{c}\text { Avg } \\
\mathrm{V}_{\mathrm{s}} \\
\mathrm{m} / \mathrm{s}\end{array}$ \\
\hline $0-1.0$ & Fill & 9.3 & 184 & 3.0 & 5.2 & 204 \\
\hline $1.0-3.5$ & Qhbm & 0.3 & 23 & 6.1 & 3.0 & 90 \\
\hline $3.5-5.4$ & Qha & 1.2 & 62 & 5.8 & 3.6 & 124 \\
\hline $5.4-8.0$ & Qpa & 2.0 & 95 & 4.7 & 3.8 & 221 \\
\hline $8-8.8$ & Sensitive & 1.0 & 30 & 3.0 & 4.1 & 212 \\
\hline $8.8-10.7$ & Qpa & 3.4 & 136 & 4.0 & 4.4 & 254 \\
\hline $10.7-$ & Sand & 17.6 & 192 & 1.4 & 8.2 & 315 \\
\hline 13.4 & & & & & & \\
\hline
\end{tabular}

\begin{tabular}{|cl|}
\hline Zone & \\
2 & Organic material \\
3 & Clay \\
4 & Silty clay to clay \\
& $\begin{array}{l}\text { Clayey silt to silty } \\
\text { clay }\end{array}$ \\
5 & Sandy silt to clayey \\
6 & silt \\
7 & $\begin{array}{l}\text { Silty sand to sandy } \\
\text { silt }\end{array}$ \\
8 & Sand to silty sand \\
9 & Sand \\
\hline
\end{tabular}




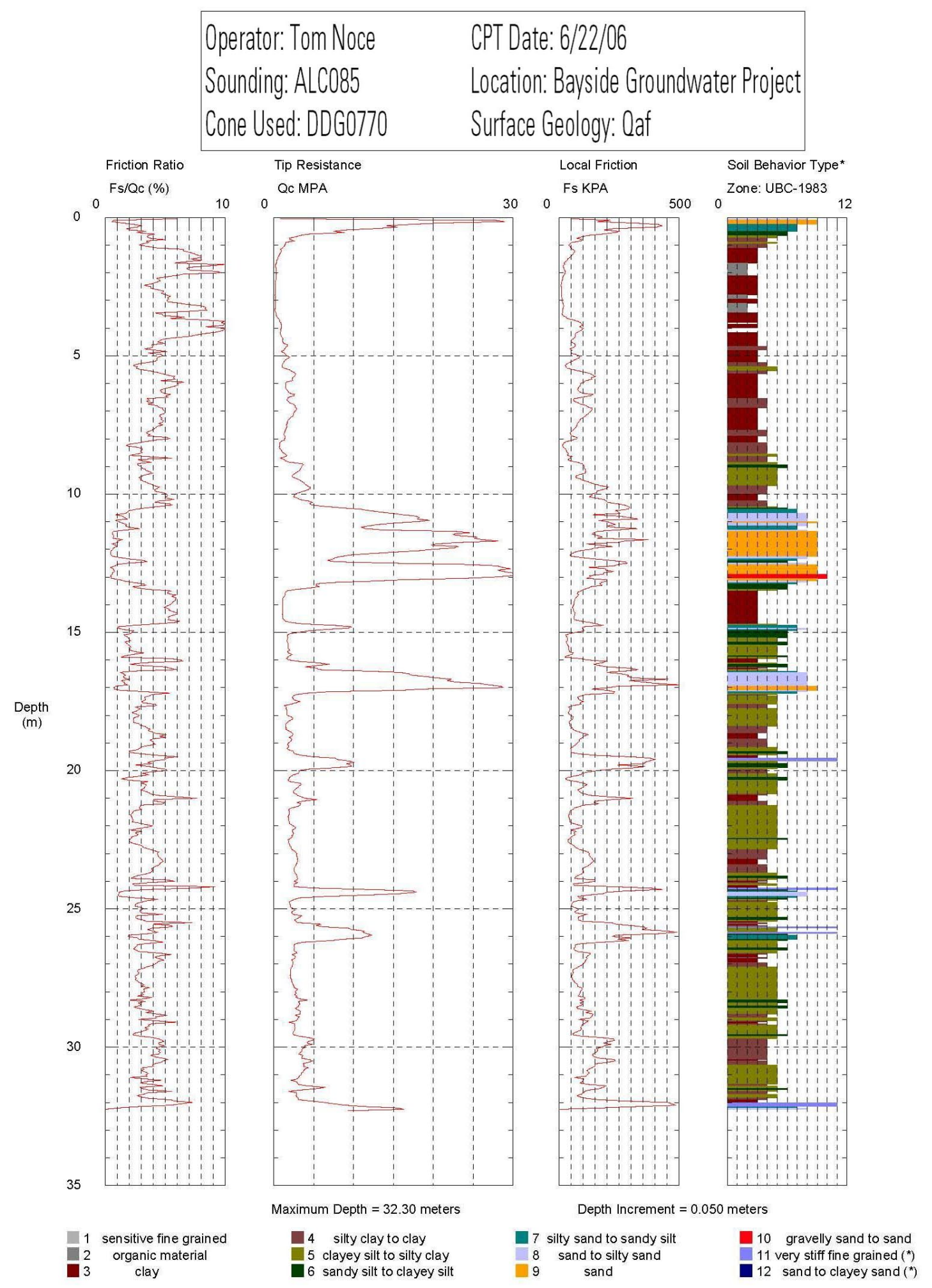

Figure 2. Hogentogler log showing friction ratio, tip resistance, local friction resistance, and soilbehavior type. 


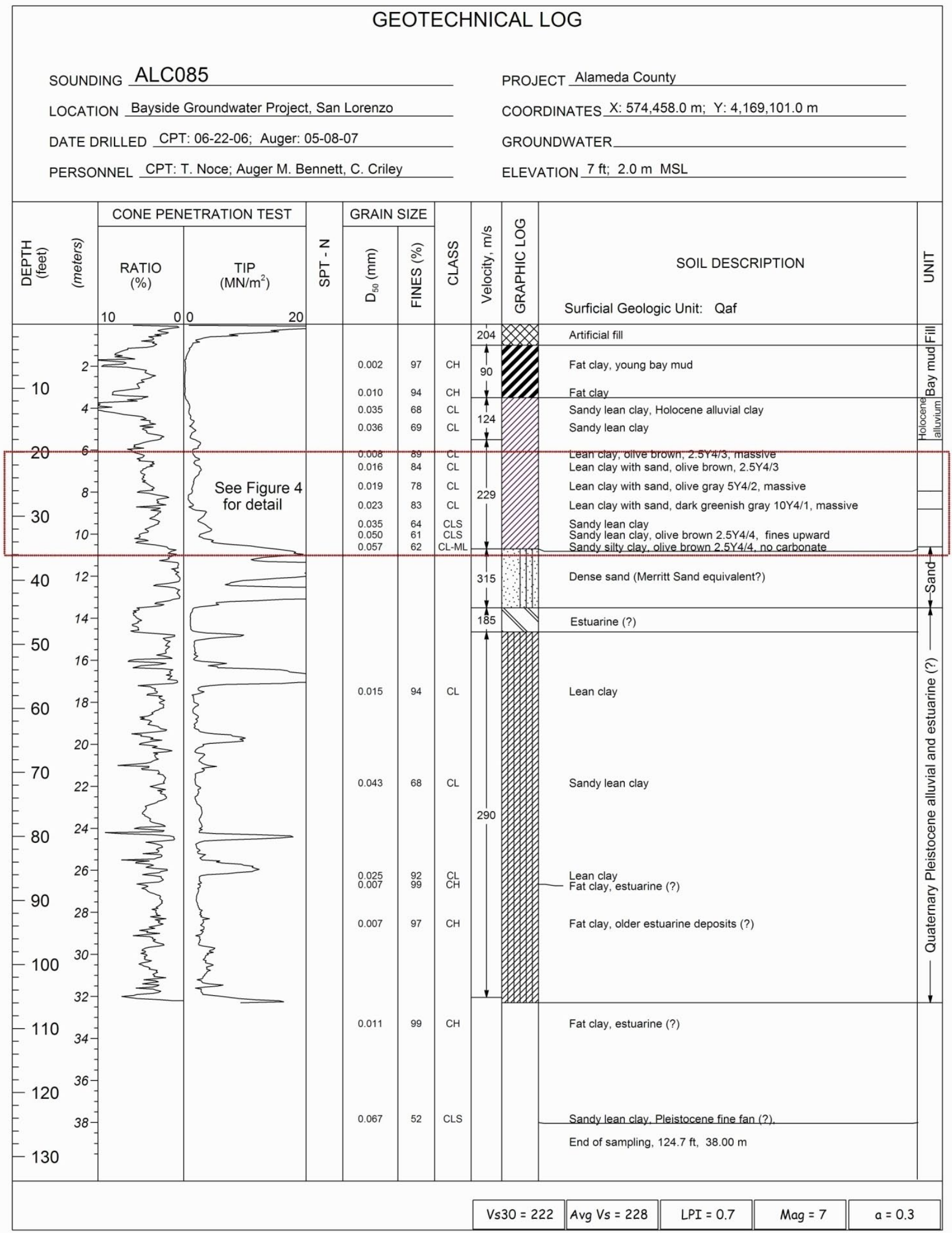

Figure 3. USGS geotechnical log showing entire sampled interval and CPT ALC085 with median grain size, fines content, soil class, shear-wave velocity, lithology, and description. See figure 4 for interval within red dotted lines. 


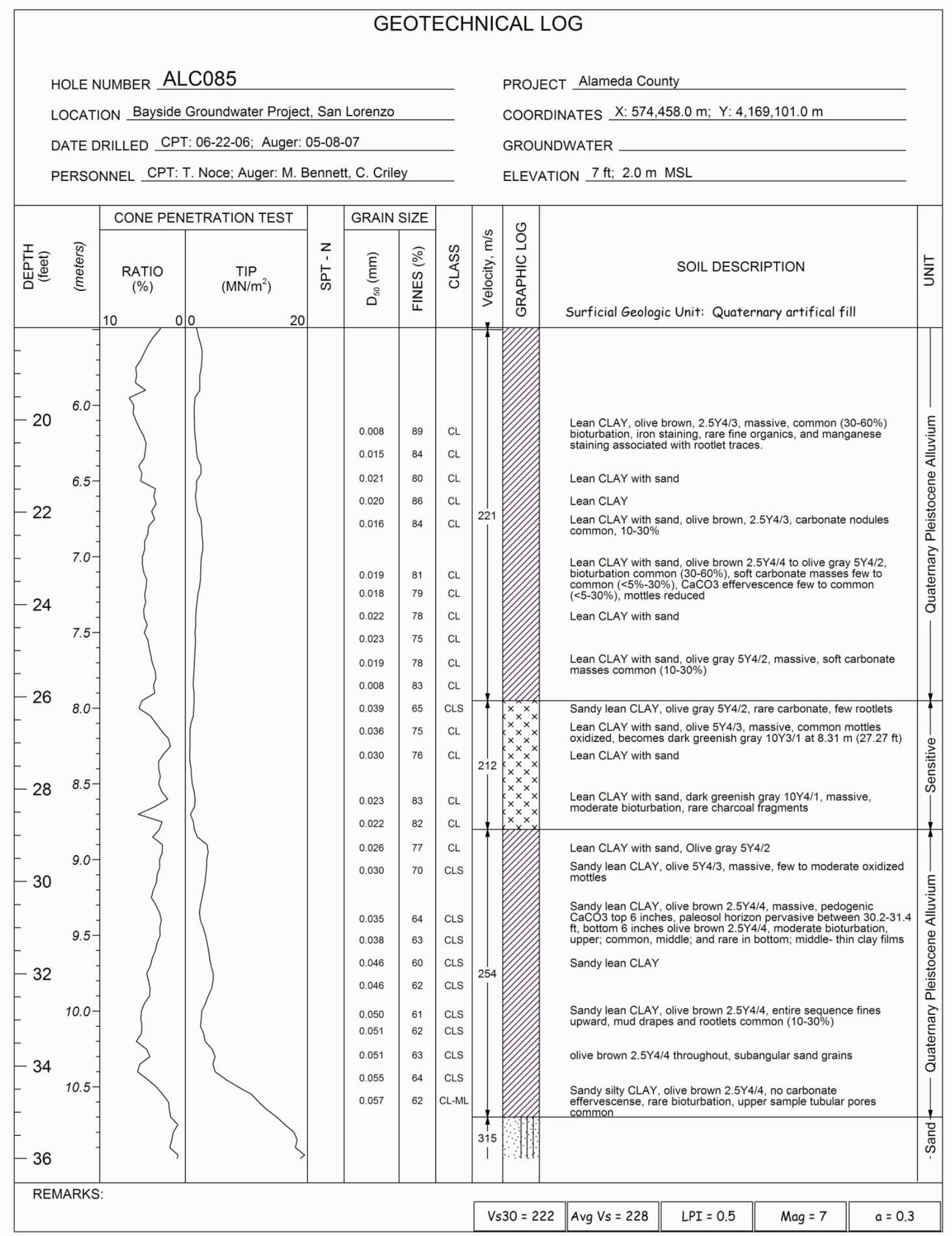

Figure 4. Detailed USGS geotechnical log showing detailed sampling interval shown in figure 3. 


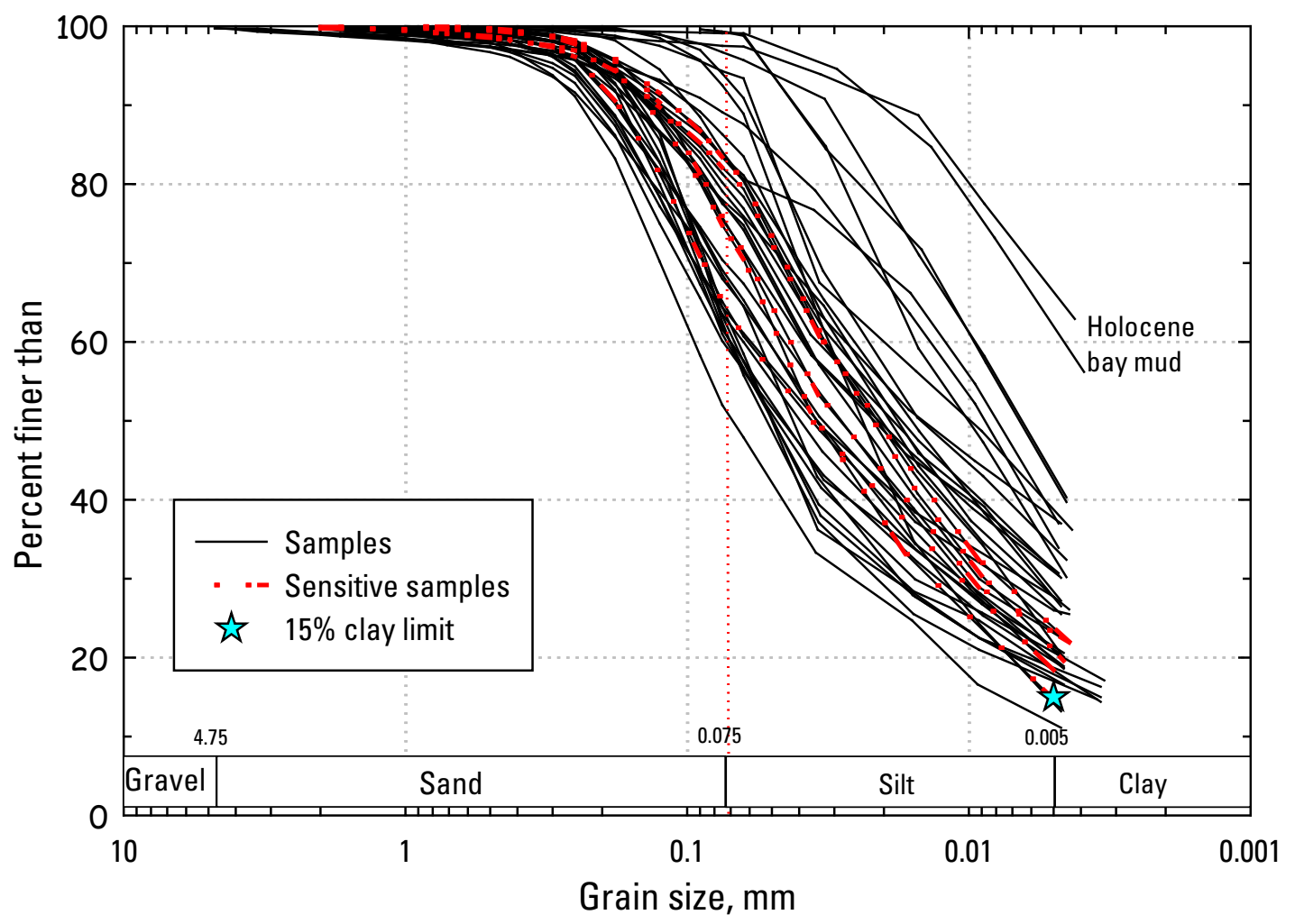

Figure 5. Graph showing grain size curves for samples from ALC085, sensitive samples shown with red dashes. Soils with 15 percent or less clay are liquefiable. The Holocene bay mud samples are the finest grained in the boring. 


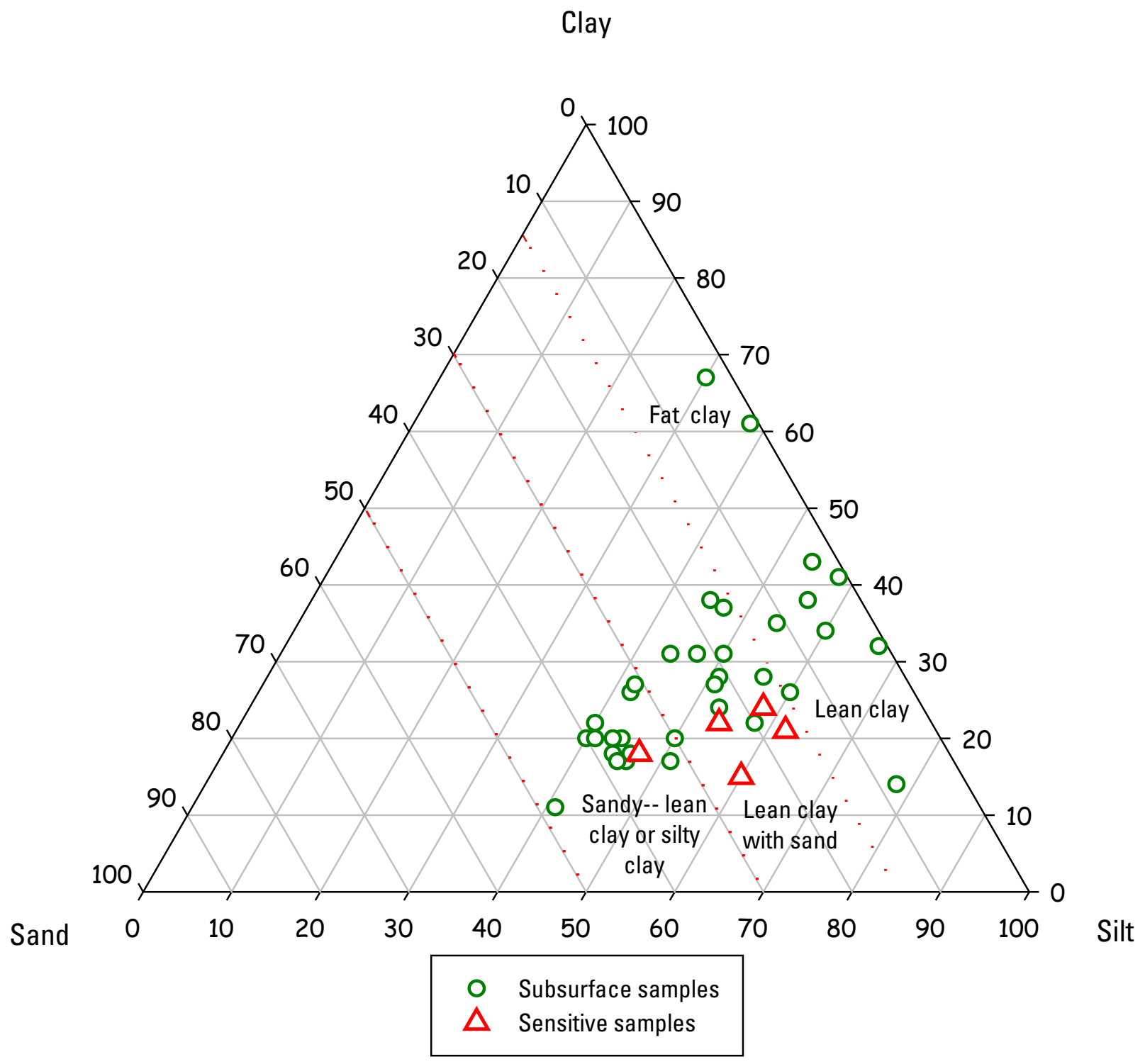

Figure 6. Graph showing samples from ALC085 plotted on a ternary diagram. Sensitive samples are marked with red triangles. Red dashed lines show boundary lines from the Unified Soil Classification System; based on fine grained soils with sand modifiers. Fat and lean clay have less the 15 percent sand, lean clay with sand has between 15 and 29 percent sand. Sandy lean clay or sandy silty clay has greater than 30 percent sand. 


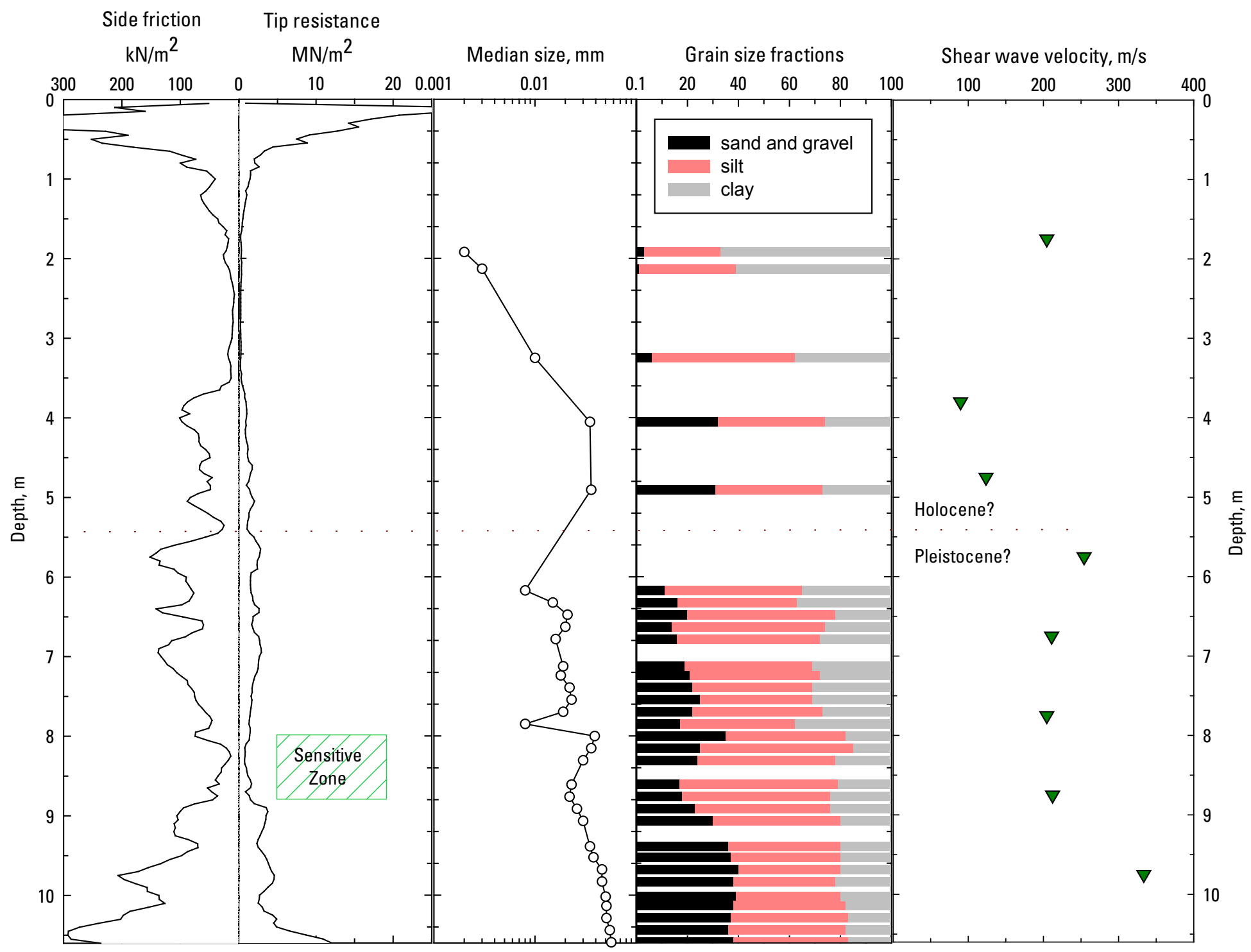

Figure 7. Graph showing side friction and tip resistance as a reference for variation in median grain size, grain size fraction and shear-wave velocity with depth. The dashed line marks the possible contact between the Holocene and Pleistocene 


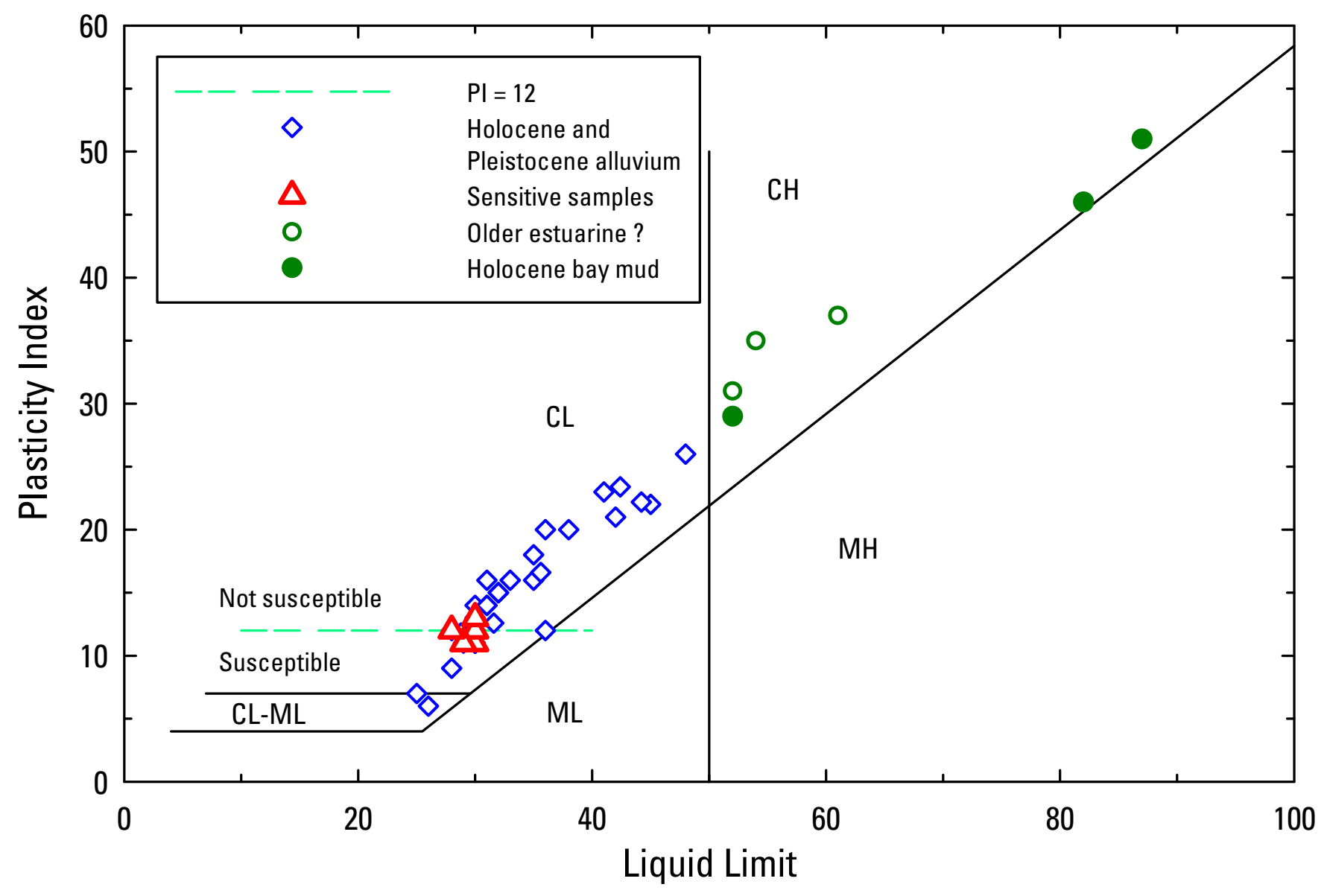

Figure 8. Graph showing plasticity chart and the relation between liquid limit and plasticity index for samples from ALC085. Holocene and Pleistocene alluvial samples are shown in blue diamonds; sensitive samples are shown in red triangles; Holocene bay mud samples are shown in solid green circles; and older estuarine (?) samples are shown in open green circles. The plasticity = 12 line is used to identify soils that are susceptible and not susceptible to liquefaction. 


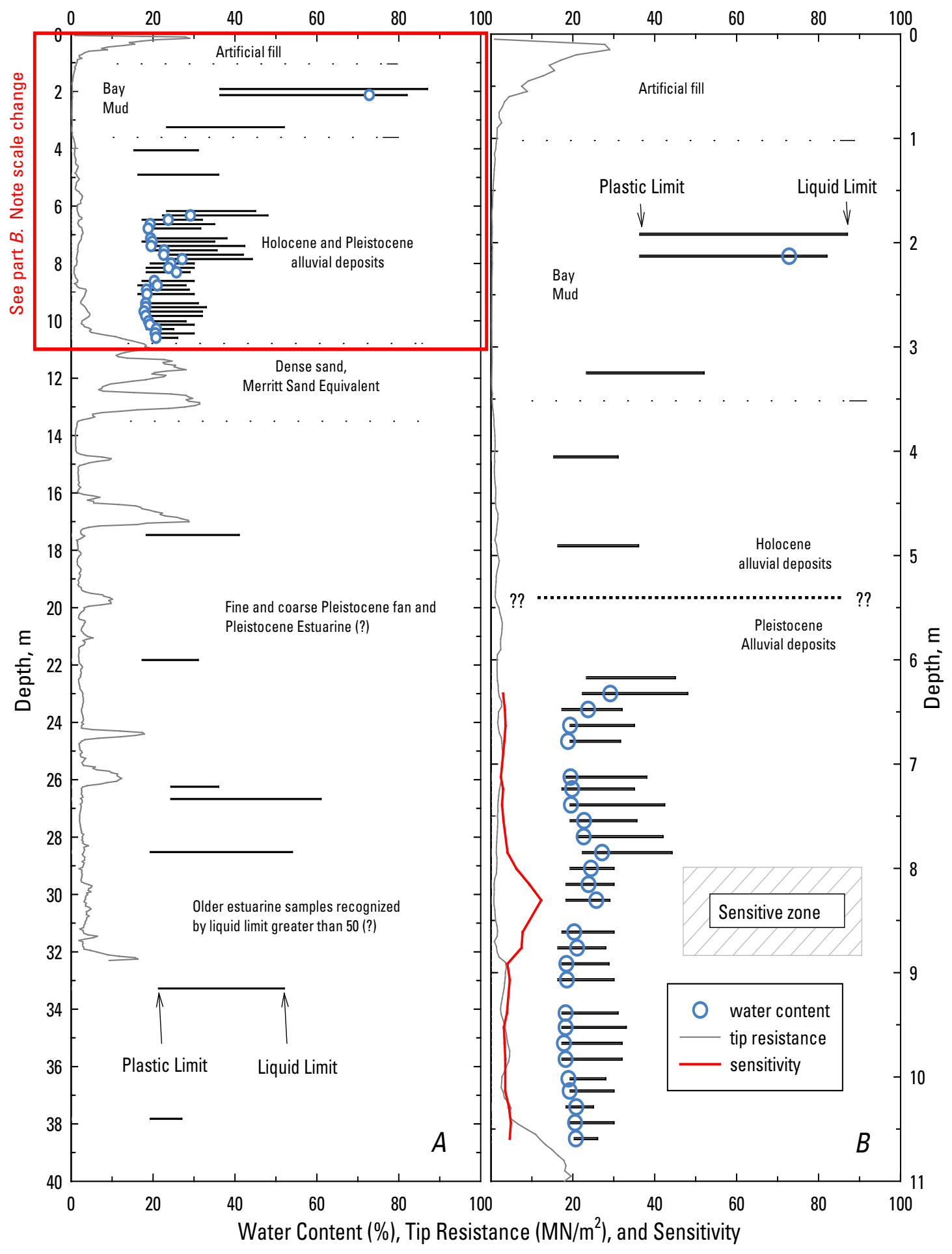

Figure 9. Graphs showing variation in Atterberg limits and water content with depth for $(A)$ entire boring and $(B)$ detailed interval 0-11 m, which also shows sensitive zone from 8.0 to $8.8 \mathrm{~m}$. Note the scale change from part $A$ to $B$. 


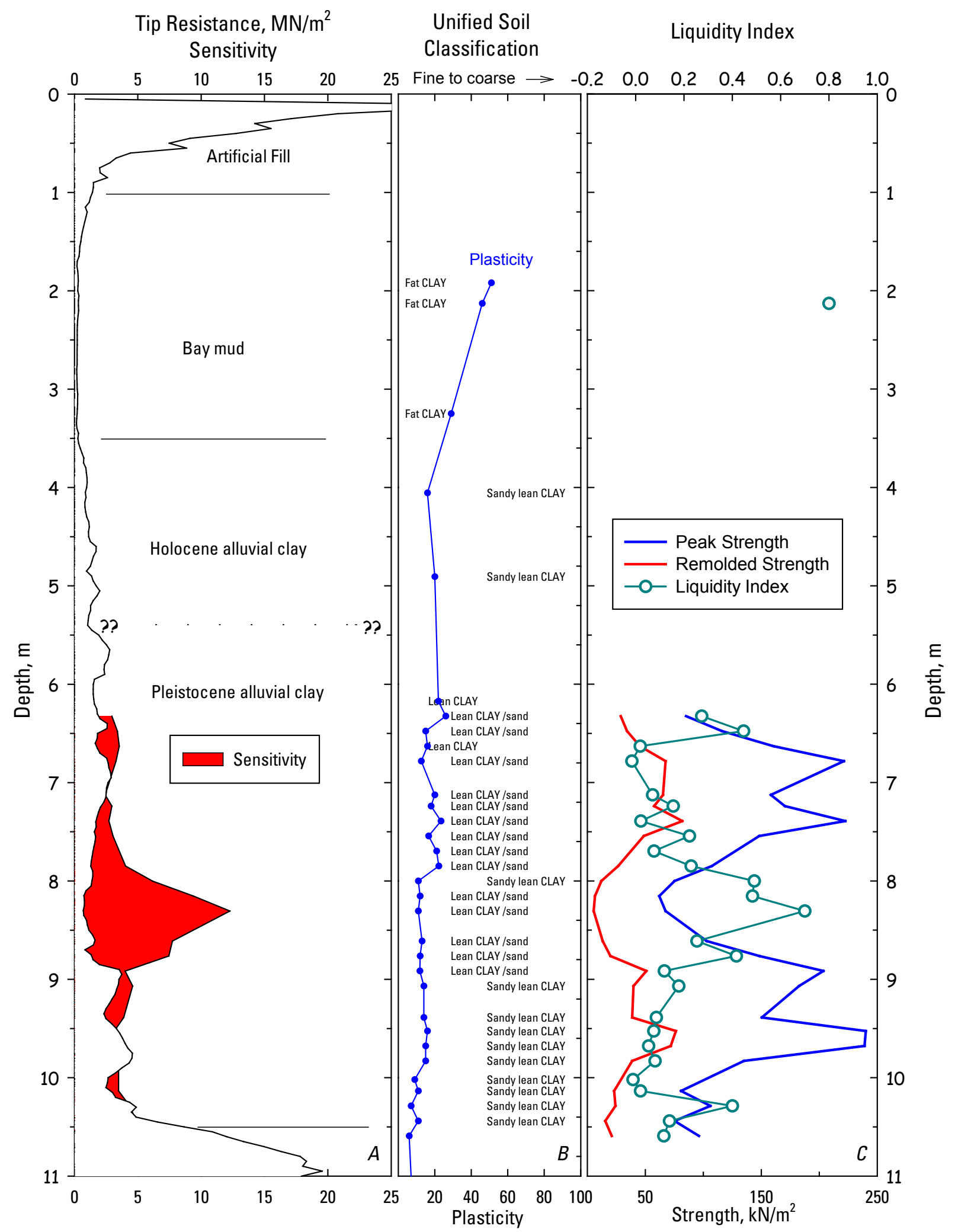

Figure 10. Graphs showing tip resistance as reference with variation in $(A)$ sensitivity, $(B)$ plasticity and soil type, and $(C)$ peak and remolded strength and liquidity index with depth. Soil type $(B)$ coarsens from left to right. 

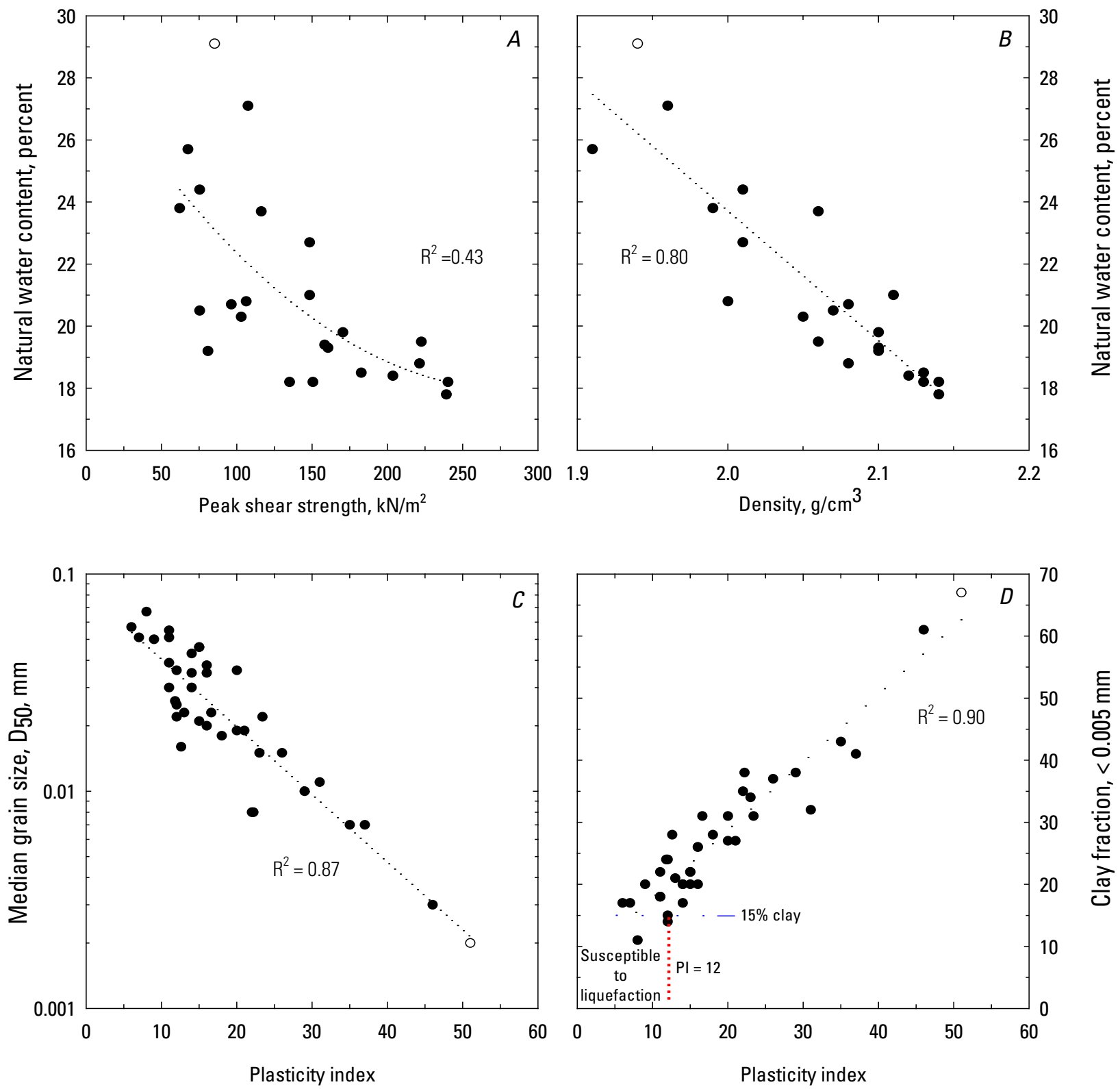

Figure 11. Graphs show relations between; $(A)$ natural water content and peak shear strength, $(B)$ natural water content and density, $(C)$ median size and plasticity index, and $(D)$ clay fraction and plasticity index of samples from ALC085. 

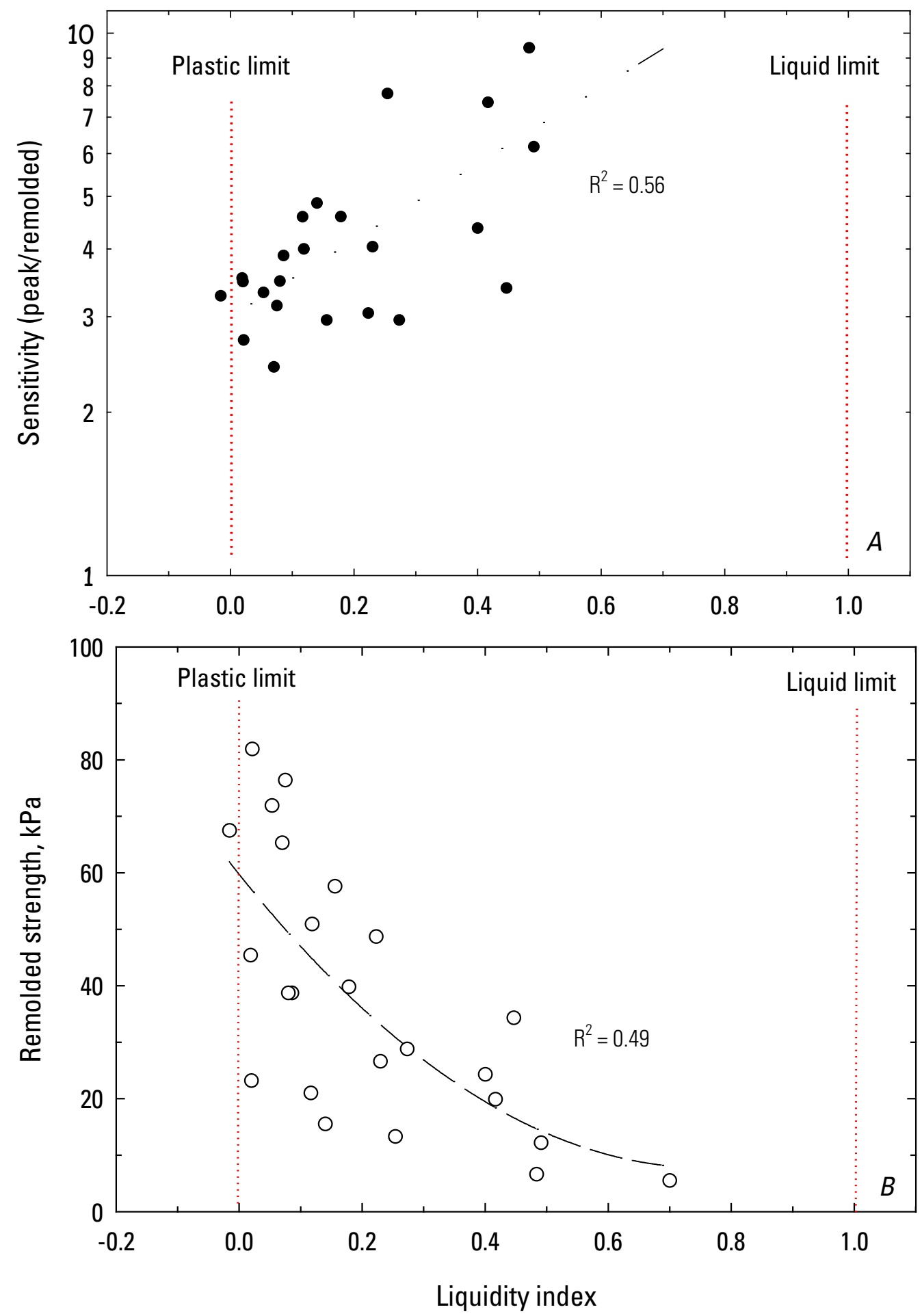

Figure 12. Graphs showing relations between liquidity index and $(A)$ sensitivity and $(B)$ remolded strength for samples from ALC085. 

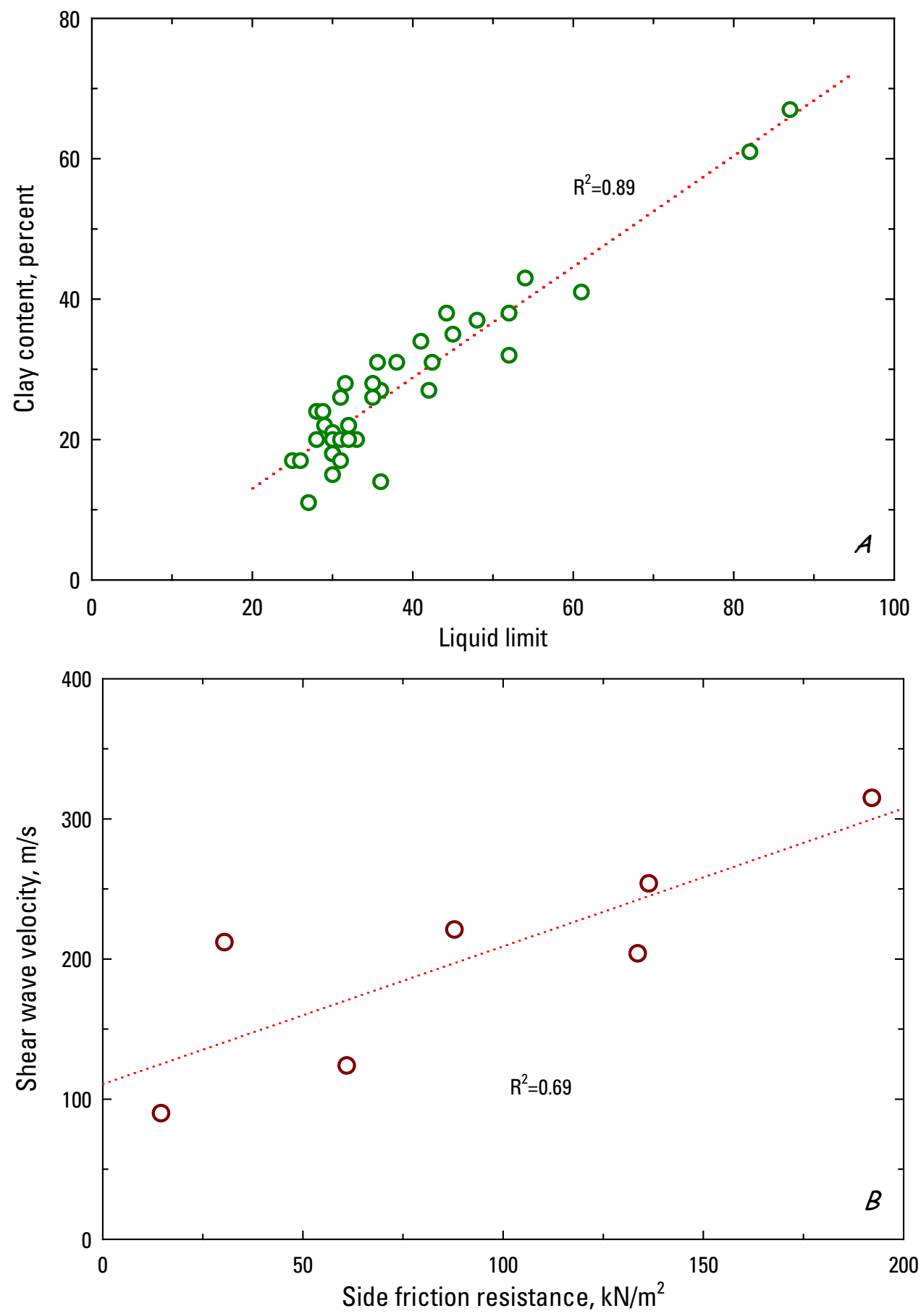

Figure 13. Graphs showing relations between $(A)$ clay content and liquid limit and $(B)$ unit shear wave velocity and side friction for samples from ALC085. 


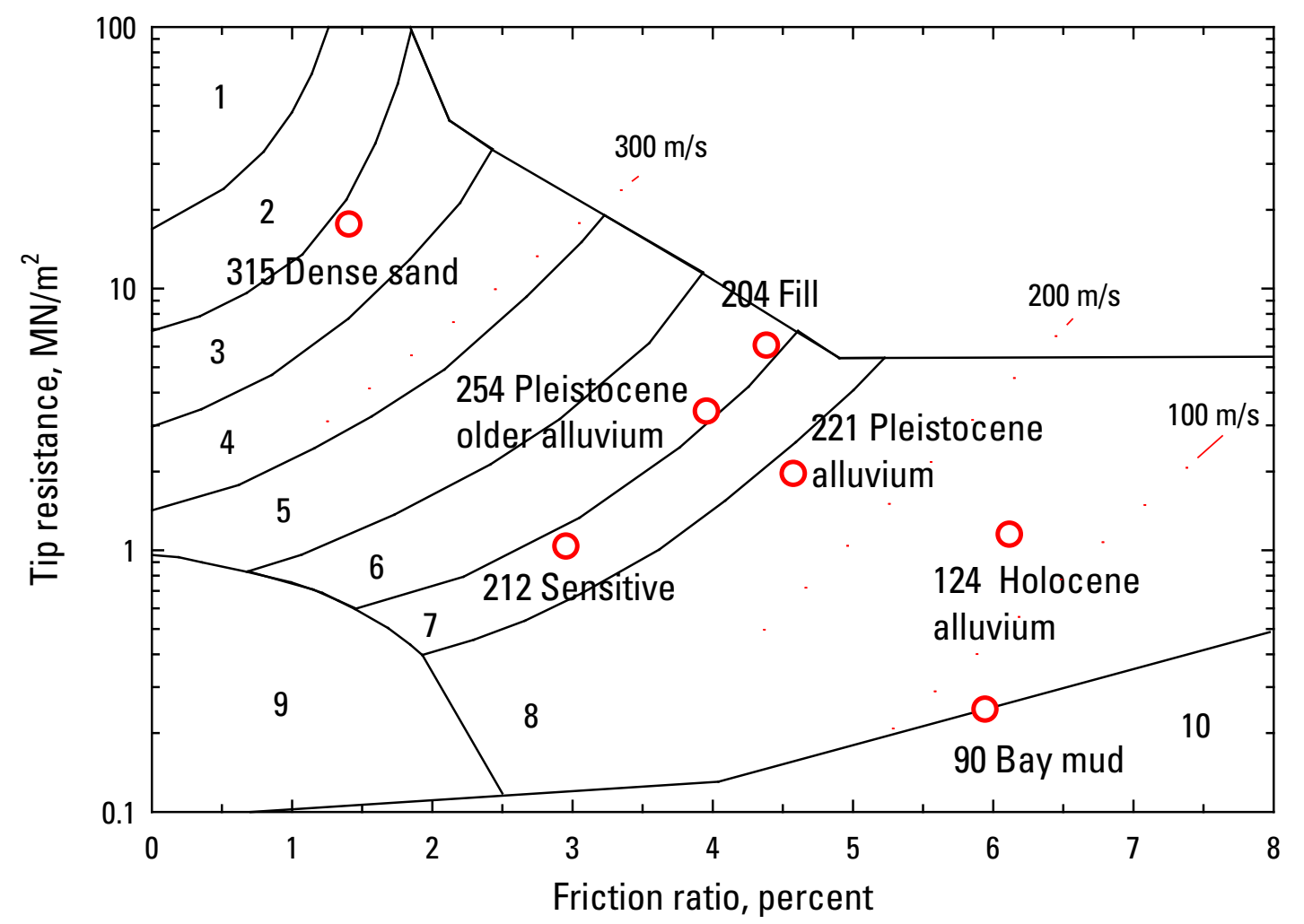

Zone descriptions

\begin{tabular}{|llc|}
\hline 1. gravelly sand & 5. silt & 9. sensitive \\
2. sand & 6. clayey silt & 10. organic \\
3. silty sand & 7. silty clay & \\
4. sandy silt & 8. clay & \\
\hline
\end{tabular}

Figure 14. Graph showing relations among friction ratio (side friction/tip resistance, percent) tip resistance, and shear-wave velocity $(\mathrm{m} / \mathrm{s})$ of stratigraphic units. Zones 1 to 10 are outlined by solid lines. The shear-wave-velocity contours (dashed red lines) are only meant in a general way to show the increase of velocity with increasing tip resistance and decreasing friction ratio of stratigraphic units from ALC085. 

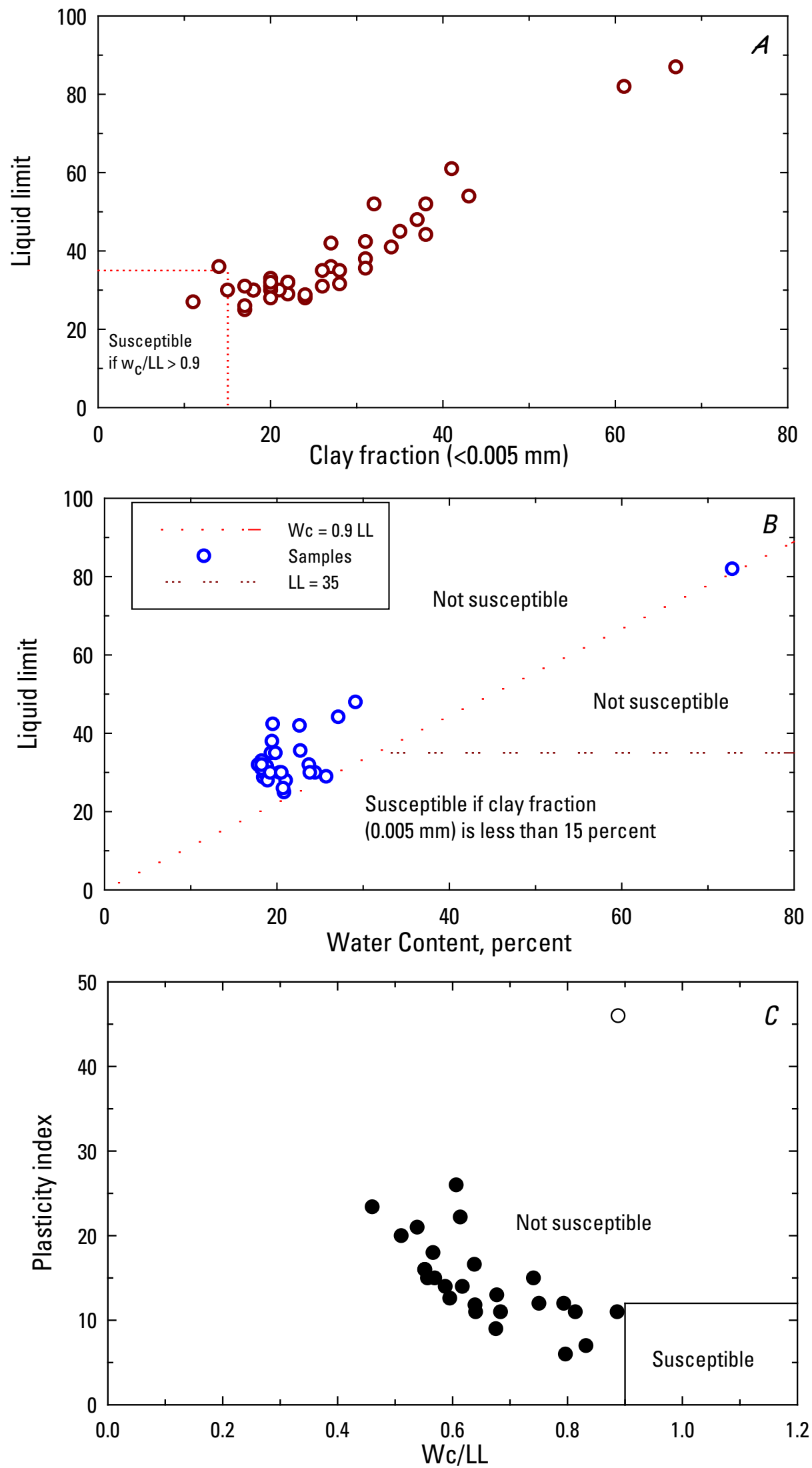

Figure 15. Graphs showing different means of classifying susceptibility to liquefaction. $A$, Liquid limit ( $<35$ percent) and clay fraction ( $<15$ percent). $B$, Liquid limit and water content ( $>0.9$ of LL). $C$, Plasticity index (<12 percent) and water content/liquid limit ratio (>0.9). 
Torrance (1983) makes it clear that the soil in the sensitive interval would not be classed as quick because the sensitivity is less than 30 and the remolded strength is greater than $0.5 \mathrm{kPa}$ (the behavior of a viscous fluid). The origin and significance of this sensitive soil is unknown, but very sensitive soils are susceptible to flow sliding and excessive consolidation. This soil is at a depth of 8 $\mathrm{m}$ on a very flat slope with no free face, therefore movement is unlikely and the $0.8-\mathrm{m}$ thickness is unlikely to produce significant settlement. Any increase in pore pressure in the sensitive zone is unlikely to destabilize overlying soil because of its nonsusceptiblility to liquefaction (fig. 15).

\section{Stratigraphic Correlations}

The upper $1 \mathrm{~m}$ of soil at the site is composed of compacted silty sand to sand. The sand is underlain by $2.5 \mathrm{~m}$ of soft Holocene bay mud as inferred by organic content, grain size, plasticity, color, and stratigraphic position. Two meters of upward-fining alluvial lean clay with sand (CL) to sandy lean clay (CLS) underlie the bay mud. The depth interval 5.4 to $10 \mathrm{~m}$ is an alluvial sequence of lean clay with sand to sandy lean clay; within this layer is a $0.8-\mathrm{m}$ - thick sensitive zone (figs 3,7 , and 10).

The SCPT indicates that between 10 and $13 \mathrm{~m}$ is dense sand (unit is unsampled) with a gravelly base (fig. 2). We correlate this unit with the Pleistocene Merritt Sand, a sand deposit common on the east side of San Francisco Bay originally mapped by Trask and Rolston (1951) as separating the old bay mud from the young bay mud. Below this unit lies mostly lean to sandy lean clay with a few sand interbeds less than $1 \mathrm{~m}$ thick and interbeds of fat clay $(\mathrm{CH})$ (figs. 2 and 3 ).

An important time horizon within the profile is the Holocene/Pleistocene $(\mathrm{H} / \mathrm{P})$ boundary. No dated material from the boring has been returned, but an estimate can be made using geotechnical and geologic characteristics. Firstly, the boundary must lie between the bottom of the Holocene bay mud $(3.5 \mathrm{~m})$ and the top of the dense sand $(10.7 \mathrm{~m})$. Second, there are three geotechnical properties that show significant changes between 3.5 to $10.7 \mathrm{~m}$ depth: these properties are: (1) grain size, (2) shear-wave velocity, and 3) side fiction resistance. The median grain size shows a fining-upward pattern from about $10 \mathrm{~m}$ to about $6.2 \mathrm{~m}$, where the detailed sampling ends (figs. 4 and 7). The next two stratigraphically higher samples are significantly coarser and change from lean clay with sand to sandy lean clay (fig. 10B). This change in soil types could reflect the $\mathrm{H} / \mathrm{P}$ boundary. Unfortunately, there are no samples between 5 and $6.2 \mathrm{~m}$ depth.

Shear-wave velocity can also help define the H/P boundary because of the difference in shear-wave velocity between Holocene and Pleistocene sediments of the same type. The shear-wave velocities of the known geologic units agree fairly well with published velocities, the bay mud is 90 $\mathrm{m} / \mathrm{s}$ and the dense sand is $315 \mathrm{~m} / \mathrm{s}$. The sandy lean clay $(3.5$ to $5.4 \mathrm{~m})$ has a velocity of $124 \mathrm{~m} / \mathrm{s}$, which is significantly lower than in the stratigraphically lower lean clay with sand (5.4 to $10 \mathrm{~m})$, which has a velocity of $229 \mathrm{~m} / \mathrm{s}$. The point measurements of shear-wave velocity (fig. 7) also indicate an important change between 4.7 and $5.6 \mathrm{~m}$ depth. The minimum velocity in the bay mud $(90 \mathrm{~m} / \mathrm{s})$ shows a slight increase downward to $124 \mathrm{~m} / \mathrm{s}$, followed by a very sharp increase to about $250 \mathrm{~m} / \mathrm{s}$ at $5.6 \mathrm{~m}$, followed by a gradual decrease in shear-wave velocity to about $200 \mathrm{~m} / \mathrm{s}$. This velocity profile is similar to a typical strength profile near the surface that shows peak strength, due to desiccation, followed by a decrease in strength. Because shear-wave velocity was measured at 1$\mathrm{m}$ intervals, resolution in defining the $\mathrm{H} / \mathrm{P}$ boundary is poor. However, shear-wave velocity is directly related to side friction $(f s)$ as measured by the SCPT (fig. 13B), and side friction is measured at $0.05 \mathrm{~m}$ intervals. In figure 7 the average side friction resistance of the $124-\mathrm{m} / \mathrm{s}$ sandy lean clay is $61 \mathrm{kN} / \mathrm{m}^{2}$, whereas the average side friction resistance of the 229-m/s lean clay with sand is $88 \mathrm{kN} / \mathrm{m}^{2}$. On the basis of grain size, shear-wave velocity and friction resistance, the Holocene/Pleistocene boundary is located at $5.4 \mathrm{~m}$ depth where the side friction increases from 61 $\mathrm{kN} / \mathrm{m}^{2}$ to $88 \mathrm{kN} / \mathrm{m}^{2}$.

Seven samples from the borehole were located between about 17.4 and $37.8 \mathrm{~m}$ (from phase one drilling). Three samples of lean clay (CL) and sandy lean clay (CLS) were obtained from 
depths between 17.4 and $26.5 \mathrm{~m}$. Three samples of fat clay $(\mathrm{CH})$ were obtained from depths between 26.5 and $33.5 \mathrm{~m}$. The deepest sample is sandy lean clay (CLS), and it came from a depth of $37.8 \mathrm{~m}$. This deeper stratigraphy can be refined using a cross section and samples obtained from borings associated with the San Mateo Bridge (Atwater and others, 1977, B-B' on plate 1). The closest borings on their cross-section line to ALC085 are borings 26, 27, and 28, about $3.2 \mathrm{~km}$ south of ALC085. If the ALC085 SCPT sounding and boring log were placed on the cross section the following comparisons could be made: (1) the thickness of the Holocene bay mud would be 4.6 $\mathrm{m}$ and its base $2.4 \mathrm{~m}$ below MSL (in ALC085 the Holocene bay mud is $3 \mathrm{~m}$ thick and $1.5 \mathrm{~m}$ below MSL); (2) the top of the Pleistocene estuarine deposit (Qpe) in the cross section is $27.4 \mathrm{~m}$ below MSL, whereas the uppermost fat clay $(\mathrm{CH})$ in ALC085 is $24.4 \mathrm{~m}$ below MSL. Atwater and others (1977) show the base of the Qpe to be $35.1 \mathrm{~m}$ below MSL, whereas in ALC085 the deepest fat clay is $32 \mathrm{~m}$ below MSL. The fat clays between 26 and $33.5 \mathrm{~m}$ in the borehole are identified as estuarine on the basis of their similarity to the fat clays in the Holocene bay mud. The similarities include median grain size, color, high liquidity index, plasticity, and soil type $(\mathrm{CH})$. These same similarities were found in estuarine units of four different ages in a 180-m borehole (fig. 1) at Ravenswood Point, San Mateo County, California (Bennett, 1979).

\section{Liquefaction}

The liquefaction potential index (LPI) calculated using SCPT data is very low (0.7). Within the dense sand between 10 and $13 \mathrm{~m}$ depth, the only layers that generate LPI are the minimal tip resistances associated with fine-grained interbeds. Size and plasticity tests show that almost all of the samples are not susceptible to liquefaction (figs. 11D, 15). Nearly all of the samples have clay content greater than 15 percent. All but one of the samples that have a plasticity index less than 12 have clay content greater than 15 percent or a water-content to liquid limit-ratio less than 0.9 . Thus, liquefaction potential for the soil in this boring is very low to zero.

\section{Acknowledgments}

Coyn Criley performed laboratory testing for phases one and two and assisted with field work in phase two drilling. Reviews by Raymond C. Wilson and Michael J. Rymer are greatly appreciated.

\section{References Cited}

American Society for Testing and Materials, 1983, Annual book of ASTM standards, soil and rock; building stones, Section 4: Philadelphia, Pa., American Society for Testing and Materials, $734 \mathrm{p}$.

Atwater, B.F., Hedel, C.W., and Helley, E.J., 1977, Late Quaternary depositional history, Holocene sea-level changes, and vertical crustal movement, southern San Francisco Bay, California: U.S. Geological Survey Professional Paper 1014, 15 p.

Bennett, M.J., 1979, Depositional environments and geotechnical properties of Quaternary sediment from South San Francisco Bay, San Mateo County, California: San Jose State University Master's Thesis, $134 \mathrm{p}$.

Bray, J.D., and Sancio, R.B., 2006, Assessment of the liquefaction susceptibility of fine-grained soils: Journal of Geotechnical and Geoenvironmental Engineering, v. 132, no. 9, p. 1165 1177.

Galloway, D.L., Jones, D.R., and Ingebritsen, S.E., 1999, Land subsidence in the United States: U.S. Geological Survey Circular 1182, 177 p.

Howard, A.K., 1984, The revised ASTM standard on the Unified Soil Classification System: Geotechnical Testing Journal, GTJODJ, v. 7, no. 4, p. 216-222. 
Iwasaki, T., Tatsuoka, F., Tokida, K.-i., and Yasuda, S., 1978, A practical method for assessing soil liquefaction potential based on case studies at various sites in Japan, in Proceedings of the 2d Conference on Microzonation, San Francisco, Ca. v. 2, p. 885-896.

Robertson, P.K., 1990, Soil classification using the CPT: Canadian Geotechnical Journal, v. 27, no. 1, p.151-158.

Seed, H.B., and Idriss, I.M., 1982, Ground motions and soil liquefaction during earthquakes: Earthquake Engineering Research Institute, 134 p.

Toprak, S., and Holzer, T.L., 2003, Liquefaction potential index; Field assessment: Journal of Geotechnical and Geoenvironmental Engineering, v. 129, no. 4, p. 315-322.

Torrance, J.K., 1983, Towards a general model of quick clay development: Sedimentology, v. 30, no. 4, p. 547-555.

Trask, P.D., and Rolston, J.W., 1951, Engineering geology of San Francisco Bay, California: Geological Society of America Bulletin, v. 62, p. 1079-1109. 